\title{
23. INTERSTITIAL WATERS OF BLACK SEA CORES
}

\author{
F.T. Manheim ${ }^{1}$ and D.M. Schug, \\ Department of Marine Science, University of South Florida, St. Petersburg, Florida
}

\begin{abstract}
Black Sea interstitial waters show three major features: (1) at Sites 379 and 380 a clear reflection of fresh-water lake stages is obtained. Data from Site 379 indicate that waters in the "Riss" fresh-water or regressive stage, as indicated by Zhuze and Mukhina (this volume), were even fresher than in the latest "Würm" regression and glacial maximum. In the former, chlorinitis of less than $2 \%$ were found, contrasting to about $3 \%$ for the "Würm." No fresh-water stage was found at Site 381, indicating truncation or nondeposition of sediments. (2) Beneath the fresh-water zones (Mindel zone, according to Zhuze and Mukhina, this volume) hypersaline episodes occur, reaching more than $100 \%$ salinity, but there are no permanent evaporitic sediments, such as gypsum. These zones exhibited high calcium and magnesium concentrations. The Black Sea in late Miocene time had waters of more standard marine character in the vicinity of Site 381, and no evaporites occur within middle to late Miocene sediments at this site or, by inference, the remainder of the Black Sea. (3) Many strong diagenetic features occur, including $\mathrm{NH}_{4}$ concentrations considerably exceeding those of $\mathrm{K}$ in pore fluids, absence of $\mathrm{SO}_{4}$, and reaction of both $\mathrm{Mg}$ and $\mathrm{Na}$ with calcium-bearing phases to form diagenetic minerals and liberate $\mathrm{CaCl}_{2}$. Silica concentrations are high in diatom-rich zones and lower in clayey sediments, which lack amorphous silica in large quantity.
\end{abstract}

\section{INTRODUCTION}

The Black Sea is a classical laboratory for the investigation of pore fluids, and frequent analyses of this type have been made in its surficial sediments (see review by Manheim and Chan, 1974). The present drillholes provided an exceptional opportunity for deeper exploration of pore fluid phenomena, paleohydrology, and diagenesis.

As first pointed out by Bruevich and Shishkina (1959), most Black Sea pore fluids in near-surface waters decrease sharply in salinity with increasing depth in the cores, a behavior attributed to influence of the Pleistocene isolation of the Black Sea, with consequent freshening of the lake stage waters to a level later calculated by Manheim and Chan (1974) to be about $3.5 \% \mathrm{Cl}$. This condition existed roughly 21,000 m.y.B.P. to 8000 m.y.B.P. and affected sediments deeper than about 1-2 meters from the surface. Owing to diffusion, however, the boundaries of original salt distribution have been smoothed and pore waters decreased roughly linearly with depth to the maximum depth penetrated, which was about 14 meters (Figure 1).

'Current address: U.S. Geological Survey, Woods Hole, Massachusetts.

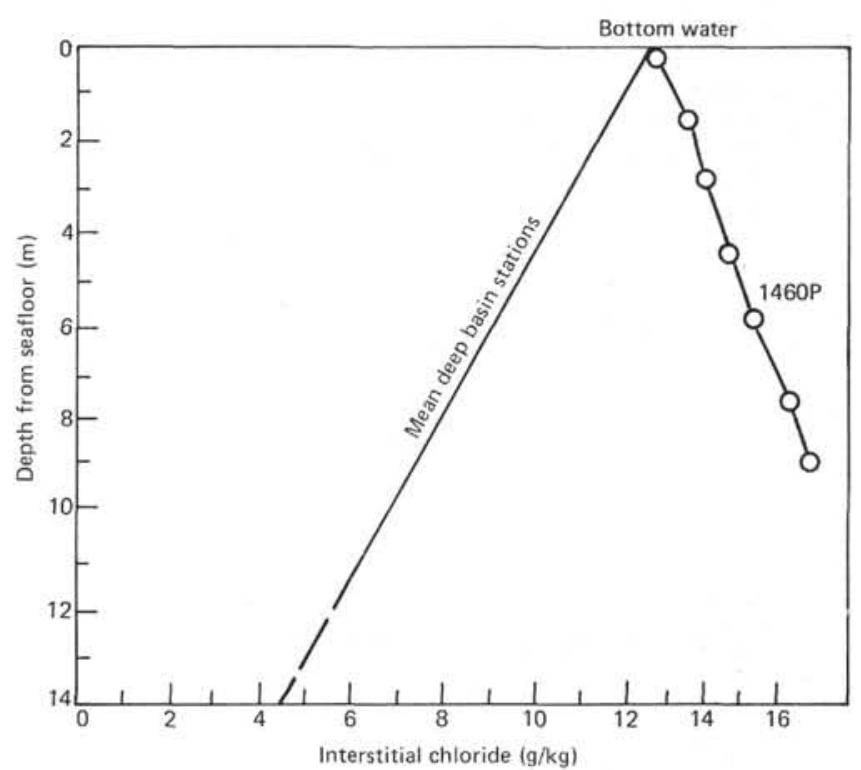

Figure 1. Mean distribution of interstitial chlorinity with depth for shallow cores in the Black Sea Deep basin (from Manheim and Chan, 1974). Anomalous behavior is shown by samples from Station 1460.

Interestingly, one location on the Black Sea shows a marked deviation from this behavior, displaying an increase in salinity and chlorinity with depth. This area 
is depicted in Figure 2, which maps chlorinity distributions at 2 meter depth in cores. As may be noted, the general center of the anomaly area is near, but not immediately opposite the Bosporus strait. It was speculated that this increase might be due to the influence of local evaporite strata or evaporiteinfluenced saline brines at depth (Manheim and Chan, 1974). The increase could not have been due to influence of Mediterranean waters, since $\mathrm{D} / \mathrm{H}$ measurements by I. Friedman (Appendix, this chapter) show lighter (lower) $\mathrm{D} / \mathrm{H}$ ratios in pore fluids with depth, like sediment pore fluids in the rest of the Black Sea.

Other puzzling phenomena that were left unexplained in previous studies were the marked increase in calcium with depth and concomitant depletion of sodium in pore fluids. The hydrochemical history of the Black Sea during the Pleistocene glacial fluctuations and world sea levels also remained poorly understood, notwithstanding studies by A.D. Arkhangelskii and colleagues in the Soviet Union, who interpreted Black Sea history through study of terrace deposits around the periphery of the sea (Muratov, 1961; Wall, 1974, and references cited). This gap in understanding is due to the fact that only transgressive deposits are normally preserved for investigation. Regressive states of the Black Sea are represented largely by a few submerged terraces and whatever evidence can be pieced together from biologic remains, and chemical and geological evidence in the cores.

Pore fluid data in the drill cores, as will be noted later, combined with other information to contribute major insights into the Pleistocene and earlier hydrologic and hydrochemical regimes. Although the analytical operations anticipated for the pore fluids have been completed and are reported here, it has not been possible to complete mathematical computations relating the data to reconstructed original salinities in the Black Sea at given periods in stages of the Black Sea Pleistocene. For this a resolution of the age data from floral and faunal evidence, which is still unsettled or controversial at this writing, is needed. This paper will therefore present the broad features relating to interstitial chemical composition and offer some qualitative interpretations relating these distributions to hydrology and sedimentary-diagenetic history of the Black Sea.

\section{METHODS}

Shipboard techniques follow previous methods described in Manheim and Sayles (1974) and references cited therein for pore fluid studies done by the DSDP, with the exception of procedures for shipboard calcium and magnesium introduced by J.M. Gieskes. Samples

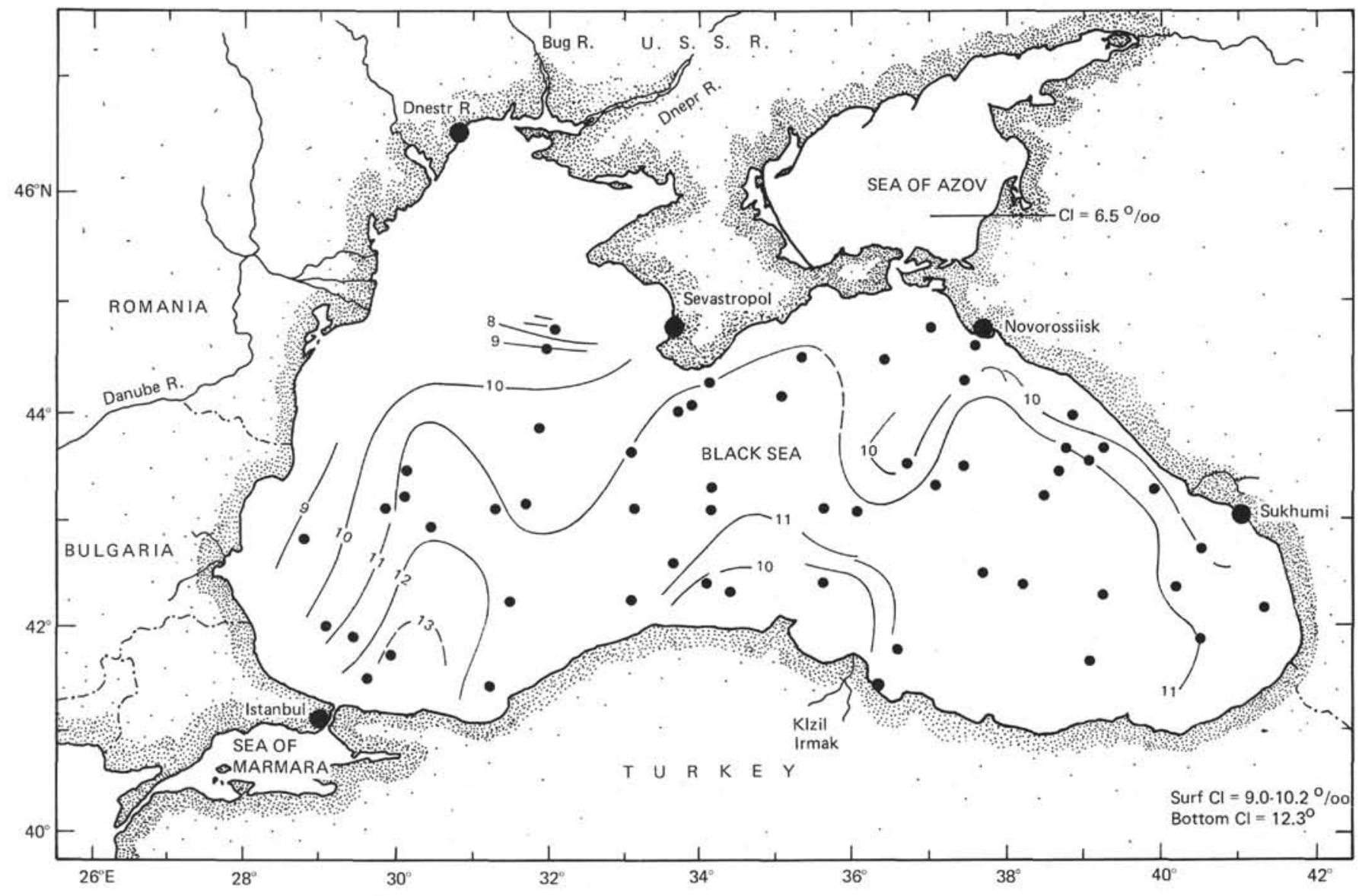

Figure 2. Distributions of interstitial chloride in piston cores (2 $m$ depths) in the Black Sea (from Manheim and Chan, 1974).

Contours refer to $\mathrm{g} / \mathrm{kg}$ cl concentrations. 
from the interior of $10 \mathrm{~cm}$ end or other sections of core were squeezed in large stainless steel squeezers at pressures up to $11,000 \mathrm{~kg}$ total load. Effluent collected in plastic disposable syringes was expelled through micropore filters to remove particulate matter, and then used for shipboard analysis. Remaining fluid was heat sealed in glass ampules and plastic pipe for shore laboratory studies.

Immediate analyses included total salt content by refractometer (temperature compensated), employing the formula for apparent salinity $\mathrm{S} \%=\Delta \Delta \times .55$, $p \mathrm{H}$, alkalinity, $\mathrm{Ca}$, and $\mathrm{Mg}$. From 25 to $1 \mathrm{ml}$ fluid was archived, depending on its availability (degree of consolidation of cores). Time permitted only a limited check for the purpose of standardizing for the influence of temperature on effluent. However, the magnitude of the changes in interstitial water compositions is much larger than possible changes heretofore noted owing to the temperature effect (Mangelsdorf et al., 1969; and subsequent authors). Based on the temperature gradients (Erickson, 1976, this volume) temperature roughly analogous to laboratory temperatures will be found at 400 to 500 meters depth, where the systematic effect should approach zero.

The laboratory studies consisted of the following analyses:

Specific gravity: Grunbaum pipette $(500 \mu \mathrm{l})$,

Chlorinity: coulometric titration (Buchler chloridometer).

$\mathrm{Na}, \mathrm{K}, \mathrm{Ca}, \mathrm{Mg}$ : atomic absorption spectrophotometry, using $\mathrm{LaCl}_{3}$ matrix,

$\mathrm{SO}_{4}$ : Titration with $\mathrm{BaCl}_{2}$ using Thorin as indicator, after removal of cations by cation exchange,

$\mathrm{Si}, \mathrm{PO}_{4}, \mathrm{NH}_{4}$ : Technicon Autoanalyzer.

Special shipboard tests included a check on temperature influence by squeezing sediment at varying temperatures. Samples from Core 379A-58 (553 m), were divided into two portions. One was squeezed at ambient temperature $\left(23^{\circ} \mathrm{C}\right)$ and the other was refrigerated at $9^{\circ} \mathrm{C}$. It was then squeezed within 10 to $15 \mathrm{~min}$ to gain a semiquantitative impression of differences. The core may not have been a good choice because $\mathrm{Ca}$ and $\mathrm{Mg}$ were already quite concentrated (96 and $77 \mathrm{meq} / 1$, respectively) and no significant differences beyond analytical scatter could be established.

An additional check on influence of squeezing pressure on composition of effluent was performed by sequential squeezing at higher pressure. The test (Table 1) shows that except for the first few drops of fluid, there was no appreciable change in the composition of the bulk of pore fluid with increasing pressure. The first few drops are evidently influenced by a trace of drilling fluid-contaminated sediment remaining from the outer part of the core. A check on scraps of the watery outer "mush" revealed considerably higher interstitial salinity, on the order of $14 \%$, confirming the above presumption. At the very highest pressures utilized, a slight reduction in salinity was noted, possibly signalling the beginning of physical expulsion of absorbed water containing lower electrolyte content (Kriukov, 1971 and publications cited).
TABLE 1

Effect of Squeezing Pressure on Effluent Compositions

\begin{tabular}{ccl}
\hline Pressure $\left(\mathrm{kg} / \mathrm{cm}^{2}\right)$ & "Salinity" $(\% \circ)$ & Remarks \\
\hline 7.1 & 10.0 & Few drops \\
14 & 7.4 & Bulk of fluid \\
36 & 7.4 & Bulk of fluid \\
50 & 7.4 & Bulk of fluid \\
100 & 7.4 & Bulk of fluid \\
142 & 7.3 & Bulk of fluid \\
\hline
\end{tabular}

Influence of drilling-fluid contaminated sediments was difficult to avoid in deeper sections of sites, where highly consolidated sediments and highly saline pore fluids were present. Here only a small portion of contaminated sediments could materially influence pore fluid composition toward lower salinity values. Fortunately, contamination can be recognized by the fact that all constituents, including sulfate are influenced proportionally to the extent that dilution with surface seawater occurs. In the present case badly contaminated outer sediment layers and drilling mushinfiltrated core material was generally discarded, or in some cases indicated by parentheses in the tables or figures.

Sampling that fails to exclude the contaminated outer sediment layers and drilling mush-infiltrated core material will typically show a sawtooth, erratic pore fluid pattern even in older sediments where diffusion should smooth variations in major constituents. A possible example of the influence of artifacts from this source may be seen in the profile from Pushkina (1965) (Figure 9).

\section{Specific Gravity Determination}

Samples of fluid were drawn into Grunbaum $500 \mu 1$ pipettes, previously calibrated with distilled water at $22^{\circ} \mathrm{C}$. Weights before and after discharge and blotting of fluid from the tip were determined to a precision of $0.05 \mathrm{mg}$.

A representative group of these measurements was plotted against the comparable "salinity" determined by index of refraction to form a reference graph. This was then used for all samples from the site in question to correct shipboard and other data based on volume aliquots (pipette delivery of samples) for specific gravity and provide data in weight units, e.g., $\mathrm{g} / \mathrm{kg}$, milliequivalents $/ \mathrm{kg}, \mu \mathrm{g}$-equivalents $/ \mathrm{kg}$, etc. Note that the specific gravity measurements are not precision determinations comparable with oceanic $\sigma_{\mathrm{t}}$ usage but are utilized (and are adequate) for analytical correction only. We also recognize that the relationship between $\mathrm{S}$ $\%$ (index of refraction) and specific gravity will vary somewhat, depending on the ionic compositions of fluids. This will be discussed further later. A sample graph is provided in Figure 3.

\section{Chlorinity}

This measurement was performed by Buchler chloridometer (coulometric titration) on $0.1 \mathrm{ml}$ 


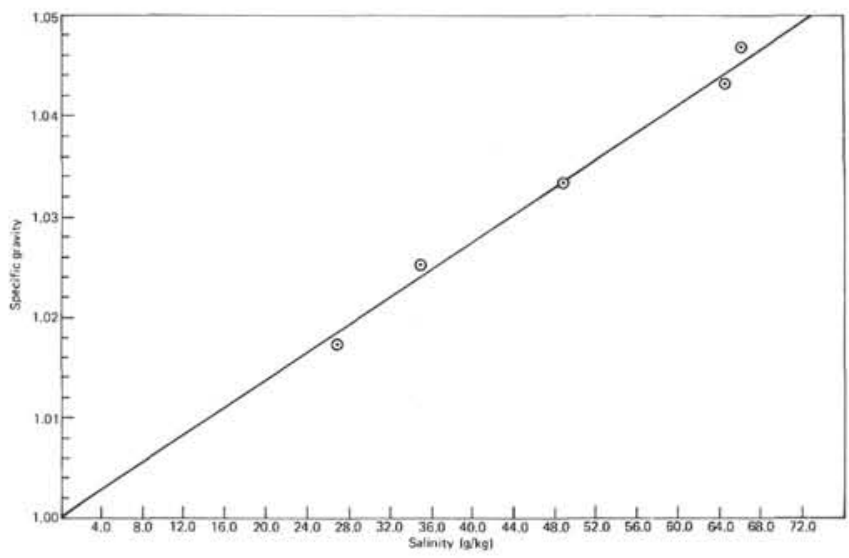

Figure 3. Plot of specific gravity against "salinity" by refractive index for Site 381. Sp. g. refers to $25 \mathrm{C}$ basis.

samples, delivered by Grunbaum pipette. $100 \mu 1$ was added to $5 \mathrm{ml}$ acid reagent $\left(\mathrm{HNO}_{3}\right.$-acetic acid-gelatin). Calibrations against Copenhagen water were performed and values from 0 to 1200 milliequivalents were used. For higher $\mathrm{Cl}$ values the corrected shipboard titration data were used and included on the table. We noted a significant systematic error in the low-value shipboard data, but higher values agreed within reproducibility of both methods as noted later.

\section{Major Cations}

All values were obtained by atomic absorption (Perkin Elmer 403). Initial samples of about $0.25 \mathrm{ml}$ were diluted to ranges bracketed by standards made from Copenhagen water and analyzed at the following wavelengths:

$\begin{array}{ll}\mathrm{Na} & 589.0 \mathrm{~nm} \\ \mathrm{~K} & 766.5 \mathrm{~nm} \\ \mathrm{Ca} & 422.7 \mathrm{~nm} \\ \mathrm{Mg} & 285.2 \mathrm{~nm}\end{array}$

Standards and samples were diluted such that the final solution contained $1000 \mathrm{mg} / \mathrm{L} \mathrm{LaCl}_{3}$ (reagent grade). The lanthanum served to suppress systematic deviations due to different ionic compositions of pore fluids and standards.

\section{Sulfate}

The microgravimetric method previously used was not employed for the deep pore fluids because of their depletion in $\mathrm{SO}_{4}$. Accordingly, the Fritz-Yamamura method of Cescon and Macchi (1973) was employed with minor modifications. In principle, diluted samples are passed through a cation exchanger to remove cations, then titrated with $\mathrm{BaCl}_{2}$ using Thorin as an indicator. The titer is established using Copenhagen seawater and accepted values of $\mathrm{SO}_{4}$ for seawater. In practice, $10 \mathrm{ml} \mathrm{H}_{2} \mathrm{O}, 1 \mathrm{ml}$ Copenhagen seawater, and 0.2 to $0.5 \mathrm{ml}$ (weighed) sample were passed through exchanger columns made from $10 \mathrm{ml}$ pipettes with Tygon tubing and clamps at the bottom. About $8 \mathrm{~cm}$ of resin was utilized below the pipette bulb.

To $5 \mathrm{ml}$ (weighed) effluent were added 4 drops of Thorin reagent $\left(0.2 \mathrm{~g} / 100 \mathrm{ml} \mathrm{H}{ }_{2} \mathrm{O}\right)$ and 10 to 18 drops diethylamine until color change to orange occurred. Then 2 to 4 drops $10 \% \mathrm{HBr}$ were added until change to yellow signified a $p \mathrm{H}$ range of 2 to 4 . The solution was then titrated to the orange endpoint using a $2 \mathrm{ml}$ microburette and $0.02 \mathrm{M} \mathrm{BaCl}_{2}$ in $80 \%$ alcohol.

The final value was determined by subtracting the $\mathrm{SO}_{4}$ due to the added Copenhagen water from the total $\mathrm{SO}_{4}$. This addition was necessary to avoid problems with blanks and otherwise stabilize the operating conditions. The approximate limits of detection were $0.03 \mathrm{meq} \mathrm{SO}_{4} / \mathrm{kg}$.

The post-exchange aliquot was chosen after discarding the first $3 \mathrm{ml}$.

\section{Nutrient Salts}

No nitrates were analyzed owing to their presumed absence in anoxic sediments, and owing to the contribution of nitrate from Millipore ${ }^{\circledR}$ filters. Other nutrients were determined by autoanalyzer techniques adapted for pore water analysis.

Ammonia was determined by the standard (Solorzano) indophenol blue reaction in alkaline phenolhypochlorite. No nitroprusside color intensifier was used, but $\mathrm{K}-\mathrm{Na}$ tartrate and citrate were added to eliminate the effect of calcium and magnesium hydroxide. Also, concentrated laundry bleach $(5.25 \%$ sodium hypochlorite) was used instead of the recommended dilution. Standards in concentrations up to $200 \mathrm{mg} / 1 \mathrm{NH}_{4}$ were prepared from $\left(\mathrm{NH}_{4}\right)_{2} \mathrm{SO}_{4}$ to accomodate the very high ammonia in pore fluids.

Phosphate was determined by the antimony phosphomolybdate method of Murphy and Riley (1962), but proved to be in extremely low values in all samples, presumably due to growth in the plastic tubes before analysis.

Silicate was determined by the method of Brewer and Riley (1966).

\section{Alkalinity}

For most of the shipboard determinations of alkalinity the mixed methyl red-methylene blue direct titration technique was utilized. In this technique a drop of indicator in alcohol is added to $1 \mathrm{ml}$ distilled water. The blank (due to dissolved $\mathrm{CO}_{2}$ ) is titrated to the endpoint and 0.1 to $2.5 \mathrm{ml}$ of sample is added while stirring and bubbling from a stream of tank nitrogen. The endpoint from green to pink is sharp. The blank titration technique was adopted only by Site 381 , hence values for Sites 379 and 380 may be too high depending on the volume of aliquot taken. As may be noted in the Discussion section, we may assume that alkalinity can be influenced by pressure decreases occurring as cores are retrieved.

\section{Calcium and Magnesium}

The titration techniques, modified for semi-micro use on board ship by J. Gieskes (personal communication), utilized the EGTA-GHA Ca method of Tsunogai et al. (1968) and the total alkali earth method using EDTA and Eriochrome Black T. As in chlorinity and alkalinity, $2 \mathrm{ml}$ hand microburettes and $15 \mathrm{ml}$ titration vials were used. 


\section{RESULTS}

Data for interstitial waters are given in Tables 2-5. Chlorinity data for the three sites are plotted in Figure 4 ; ionic composition of fluids for individual sites are depicted in Figures 5-7 as milliequivalents/kg against depths. Control data on surface water composition are given in Table 5.

For Site 379 total salt and chloride content decrease very sharply in the upper 5 to 10 meters, as has been previously noted in piston core data (Figures 1,4 ), then stay low for more than 200 meters depth below sea floor. Chlorides drop below $2 \%$, or less than $1 / 6$ of present bottom waters. Thereafter, a continuous increase in $\mathrm{Cl}$ and total salts with depth to well beyond seawater salinity values is noted. Below 200 meters a marked increase in $\mathrm{Ca}$ and $\mathrm{Mg}$ are also noted, whereas a relative depletion of $\mathrm{Na}$ with respect to $\mathrm{Cl}$ occurs. By the bottom of the hole, $\mathrm{Ca}, \mathrm{Mg}$, and $\mathrm{Na}$ are present roughly in similar quantities in terms of reaction equivalents. In contrast, $\mathrm{K}$ reaches its maximum at about 80 meters and remains at low values with increasing depth. Among organic-related constituents, the $\mathrm{NH}_{4}$ concentration increases very sharply with depth and actually exceeds that of $\mathrm{K}$ below about 15 meters depth. $\mathrm{SO}_{4}$ is depleted below a few meters, and is negligible at deeper levels.

Sites 380 and 381 show roughly comparable phenomena with Site 379, markedly affected, however, by their greater penetrations and lesser accumulation rates. In Site 381 salinities again drop to values close to current Aegean levels below hard dolomites and limestones at 380 meters.

Among biogenic species, $\mathrm{PO}_{4}$ concentrations were low, whereas interstitial $\mathrm{Si}\left(\mathrm{SiO}_{2}\right)$ varied according to lithology and $\mathrm{NH}_{4}$ was high. It reached 40 to $60 \mathrm{mg}$ atom $/ \mathrm{kg}$ in nannofossil and diatomaceous sediments, but dropped to as low as $4 \mu \mathrm{g}$-atom $/ \mathrm{kg}$ in terrigenous muds.

\section{DISCUSSION}

Interrelationship Between Sediment Age, Diffusion, and Environment

Salinity evidence is retained in Black Sea sediments, especially at Site 379 , to an extraordinary degree. Normally, the rate of diffusion of dissolved constituents in pore fluids of Recent and older sediments is great enough to rapidly obliterate details of "fossil" ocean waters.

When sediment accumulation is sufficiently rapid, the resulting thick column of sediments will retain more accurate evidence of former waters buried with sediments than for more slowly accumulating sediments. A rough measure of the rate at which diffusional migration competes with sedimentati $4 \mathrm{n}$ rate is "scale height" or the ratio of the diffusion coefficient to sediment accumulation rate, expressed in equivalent units (Lerman, 1970). Let $R_{a c}=10 \mathrm{~cm} / 1000$ years and $D_{\text {eff }}=1 / 4$ of the diffusion rate for free solution (Manheim, this volume), equal to $5 \times 10^{-6} \mathrm{~cm}^{2} / \mathrm{sec}$ or $1.6 \times 10^{5} \mathrm{~cm}^{2} / 1000 \mathrm{yr}$ for $\mathrm{Cl}$. Then

$$
\begin{aligned}
& \mathrm{D}_{\text {eff }}=\frac{1.6 \times 10^{5} \mathrm{~cm}^{2} / 1000 \mathrm{yr}}{10 \mathrm{~cm} / 1000 \mathrm{yr}}=1.6 \times 10^{4} \mathrm{~cm}=160 \mathrm{~m} \\
& \mathrm{R}_{\mathrm{ac}} \\
& \text { where } \\
& \mathrm{R}_{\mathrm{ac}}=\text { rate of accumulation and } \\
& \mathrm{D}_{\text {eff }}=\text { effective diffusion coefficient for } \mathrm{Cl} \text { in sediment. }
\end{aligned}
$$

At a $R_{a c}$ of $100 \mathrm{~cm} / 1000 \mathrm{yr}$ the scale height is reduced to only 16 meters, indicating that the rate of accumulation is beginning to seriously delay diffusive equalization of concentrations with depth, even with large concentration gradients. Lower diffusion gradients further reduce scale height. Thus, the combination of exceptionally rapid sediment deposition at Site 379 and fluctuations in water column salinity which are one to two orders of magnitude greater than the analytical precision has permitted detailed retention of "paleosalinity" indications deeper than usual, to more than 200 meters subbottom depth. Several lines of evidence for paleosalinity and other environmental indicators for the Black Sea are plotted in Figure 8. These include total sediment sulfur (Calvert and Batchelor, this volume), diatoms (Jousé and Mukhina, and Schrader, this volume), and spores and pollen (Koreneva and Kartasheva, this volume), in addition to interstitial water chlorinity.

The lowest strata show clear influence of hypersaline conditions as indicated by an increase of interstitial chlorinities and salinities relative to values of modern Mediterranean seawater. Interstitial salinities were still increasing with drilling depth at the time drilling was terminated. Details of original environmental conditions in the lowest part of the site are largely obliterated by molecular diffusion of salt. Figure 8 suggests that the latest hypersaline episode (assuming there may be more than one) terminated below 300 meters depth, in strata interpreted by Koreneva and Kartasheva (this volume) as Drevneeuxinian (Old Euxinic) or very roughly 230,000 years before present. Although Jousé and Mukhina (this volume) found diatoms absent in this interval, Schrader (this volume) indicated that diatom species compatible with fresh to hypersaline conditions were present. A regressive stage would be expected with hypersaline development, such that seawater would have at least intermittent access to the basin, but return flow from the Black Sea would be impeded. Arid conditions causing excess of evaporation over river inflow would be expected, and would be consistent with a steppe-like flora. The uppermost hypersaline strata would be expected to have lost a considerable part of their original salt content by leaching and diffusion into subsequent (overlying) fresher sediment sequences.

A marked freshwater horizon occurs above the inferred hypersaline zone. Chlorinities between 200 and 250 meters depth are as low as $1.75 \mathrm{~g} / \mathrm{kg} \mathrm{Cl}$, which are the lowest values found in Black Sea sediments. Above this, modest increases in chlorinity suggest alternating fresh-brackish conditions, dominated by fresher sequences. Another local low is found at about 35 
TABLE 2

Interstitial Water Values for Holes 379A, B

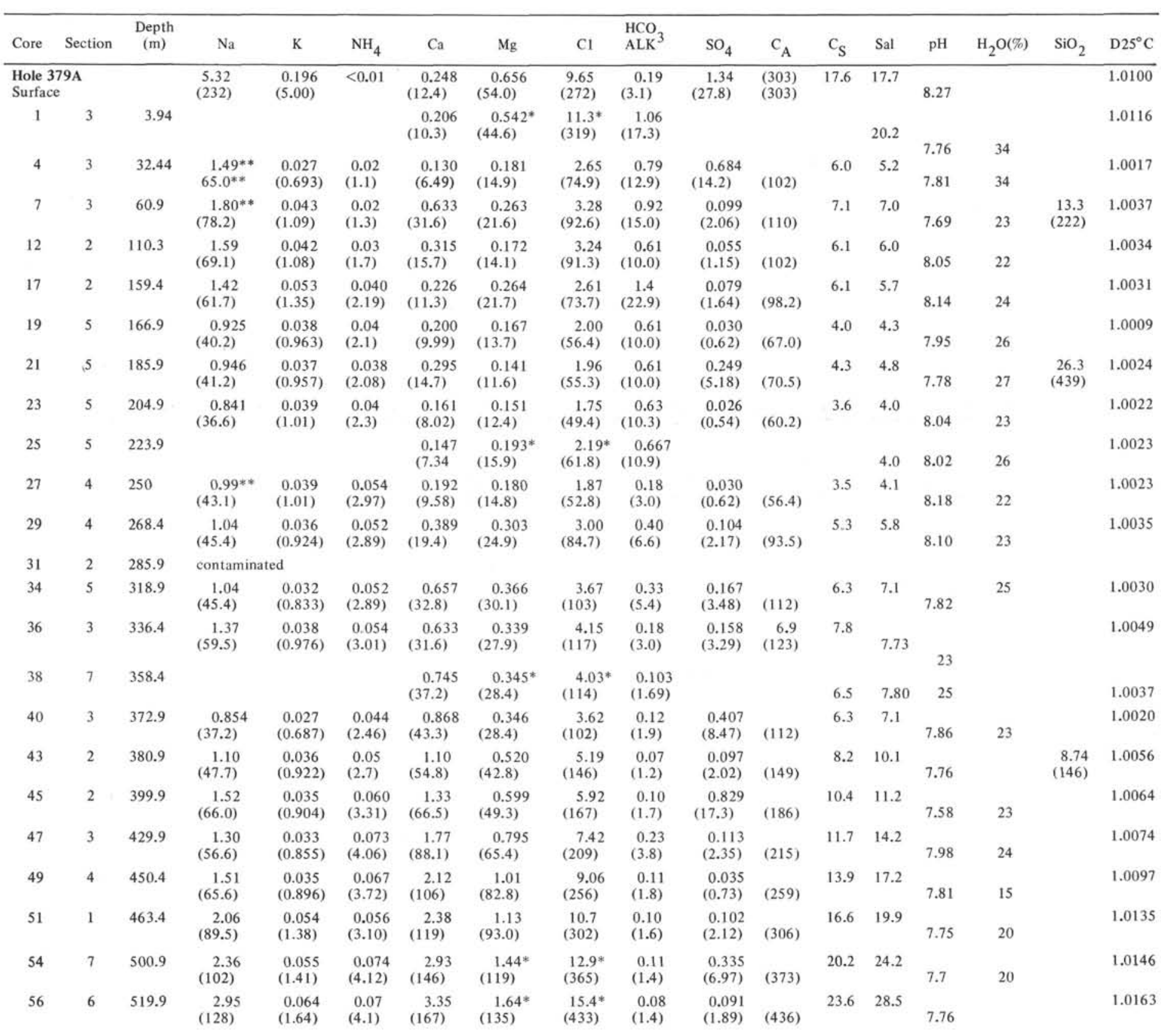




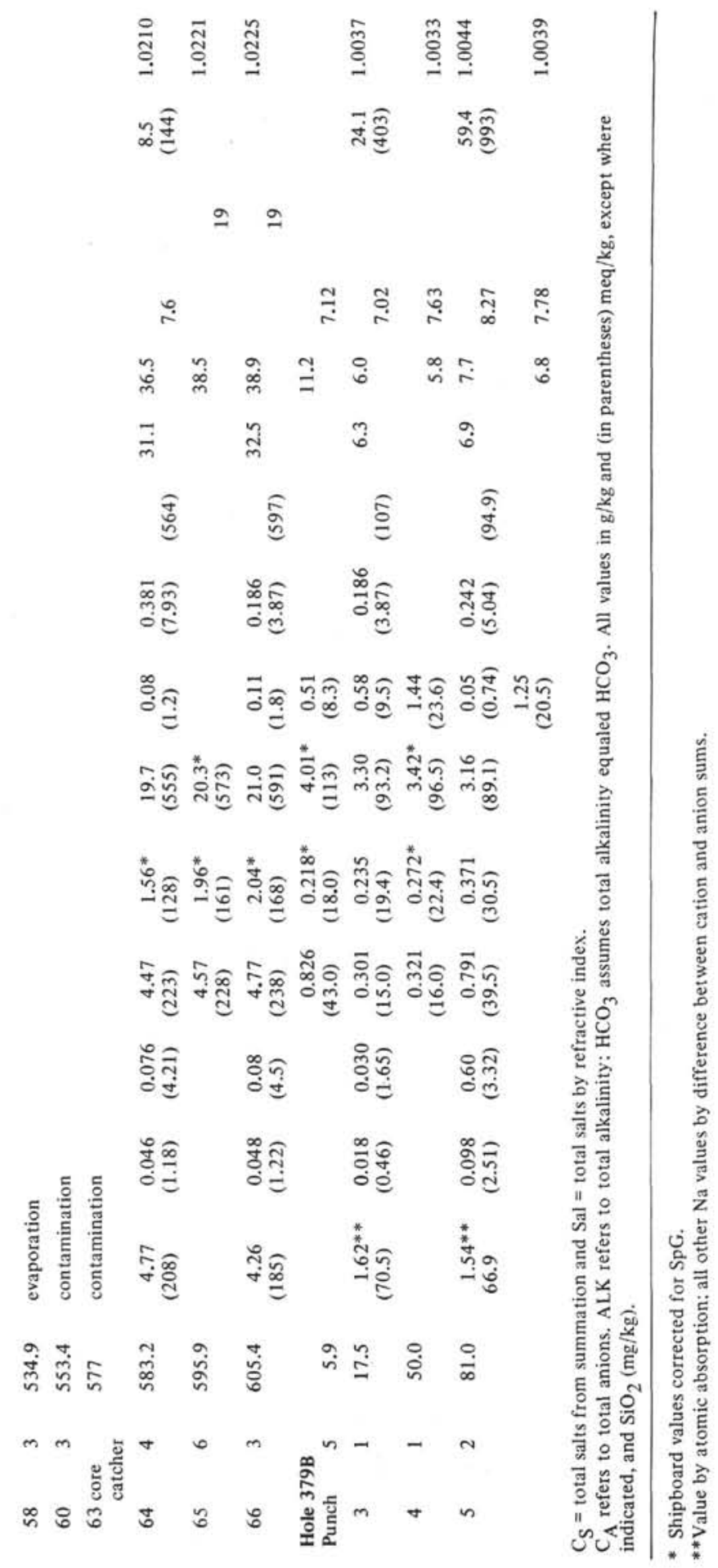

meters depth, corresponding to the most recent Novoeuxinian or Würm regression and glacial maximum (Figure 8). Above the Novoeuxinian a sharp transition occurs to present-day bottom water salinities.

As has been noted previously, diffusion is a significant force modifying original paleosalinity "signatures" on buried strata. For example, sediments during the past 6000 years are believed to have been buried under bottom water salinity levels roughly similar to those at the present time (Manheim and Chan, 1974). The sediment thickness corresponding to this time interval is only 1 to 2 meters; below this point sediments were laid down in an isolated lake stage of the Black Sea in waters having a chlorinity between 3 and $4 \%$. Yet, influence of the saltier, more recent interstitial waters extends from 10 to 15 meters into the bottom of the Black Sea. At earlier stages in the Pleistocene still greater diffusive transport is expected; calculation of these effects is being undertaken in work in progress, in order to attempt more detailed reconstruction of paleosalinity regimes.

\section{Hypersaline, Playa Lake Stage of the Black Sea}

Pore fluid composition of the three holes is dominated by the residue of a hypersaline, probably "playa" stage of the Black Sea during Pleistocene time. Some evidence limiting the time and implications of the pore fluids will be equivalently discussed here. More quantitative calculations and evaluations are still in progress and will require coordination of all the lines of evidence made available in this volume, especially those relating to age of deposits and constraints on depositional conditions and hydrologic relationships.

First, confirming evidence that the hypersaline episode was limited to the Pleistocene was provided by Site 381, which penetrated Miocene strata. Beneath a poorly permeable sequence of tightly cemented limestones and dolomites the high salinities dropped back to salinity values characteristic of the present-day Aegean Sea, or about $39 \%$. In the absence of such impermeable strata this "paleosalinity" could not have been preserved. The sharpness of the transition also implies strongly that cementation occurred not long after burial of the sediments. Lower strata would have probably been infiltrated by higher salt concentrations than noted here. Corresponding to the salinity indications $\mathrm{D} / \mathrm{Cl}$ characterize the minimum values overlying water column (Hardcastle and Friedman, Appendix, this chapter).

An additional evidence provided by the pore fluid data at the base of Site 381 is that no evaporite sequence comparable to the Mediterranean deposits (Messinian) is present in the underlying Miocene within reach of diffusional migration.

At Site 380 the cemented limestone-dolomite layer found at about 870 meters, correlative with the equivalent lithology at Site 381 , is much thinner and less tightly cemented, and has clearly not provided an equivalent barrier to downward diffusion of salt. However, one may presume that at some point below the drilled depth 
TABLE 3

Interstitial Water Data for Holes 380, 380A

\begin{tabular}{|c|c|c|c|c|c|c|c|c|c|c|c|c|c|c|c|c|c|}
\hline Core & Sec & $\begin{array}{l}\text { Depth } \\
\text { (m) }\end{array}$ & $\mathrm{Na}$ & K & $\mathrm{NH}_{4}$ & $\mathrm{Ca}$ & $\mathrm{Mg}$ & $\mathrm{Cl}$ & $\begin{array}{l}\mathrm{HCO}_{3} \\
\mathrm{AKL}\end{array}$ & $\mathrm{SO}_{4}$ & $\mathrm{C}_{\mathrm{A}}$ & $\mathrm{C}_{\mathrm{S}}$ & Sal & $\mathrm{pH}$ & $\mathrm{H}_{2} \mathrm{O}(\%)$ & $\mathrm{SiO}_{2}$ & $\mathrm{D}_{20}^{20}$ \\
\hline \multicolumn{18}{|c|}{ Hole 380} \\
\hline \multicolumn{3}{|c|}{ Surface site } & $\begin{array}{l}5.52 \\
(240\end{array}$ & $\begin{array}{l}0.212 \\
(5.43)\end{array}$ & $<0.01$ & $\begin{array}{l}0.246 \\
(12.3)\end{array}$ & $\begin{array}{l}0.686 \\
(56.4)\end{array}$ & $\begin{array}{l}10.0 \\
(283)\end{array}$ & $\begin{array}{l}0.20 \\
(3.2)\end{array}$ & $\begin{array}{l}1.35 \\
(28.1)\end{array}$ & (314) & 18.2 & 18.7 & \multirow{2}{*}{$\begin{array}{l}8.28 \\
7.76\end{array}$} & & \multirow[t]{4}{*}{0.0} & 1.0120 \\
\hline \multicolumn{3}{|c|}{ Pressure core } & $\begin{array}{r}5.63 \\
(245)\end{array}$ & $\begin{array}{l}0.179 \\
(4.59)\end{array}$ & $\begin{array}{l}0.022 \\
(1.22)\end{array}$ & $\begin{array}{l}0.625 \\
(31.2)\end{array}$ & $\begin{array}{l}0.668 \\
(55.0)\end{array}$ & $\begin{array}{l}11.2 \\
(316)\end{array}$ & $\begin{array}{l}0.70 \\
(11.4)\end{array}$ & $\begin{array}{l}0.463 \\
(9.64)\end{array}$ & (337) & \multirow[t]{2}{*}{19.5} & 20.3 & & & & 1.0129 \\
\hline 1 & 5 & 7.9 & & & & $\begin{array}{l}1.27 \\
(63.4)\end{array}$ & $\begin{array}{l}0.540 * \\
(4.44)\end{array}$ & $\begin{array}{c}9.66^{*} \\
(272)\end{array}$ & $\begin{array}{l}0.206 \\
(3.36)\end{array}$ & & & & 16.5 & 6.85 & 50 & & 1.0106 \\
\hline 4 & 3 & 34.9 & $\begin{array}{r}3.47 \\
(151)\end{array}$ & $\begin{array}{l}0.101 \\
(2.58)\end{array}$ & $\begin{array}{l}0.04 \\
(2.0)\end{array}$ & $\begin{array}{l}1.08 \\
(53.8)\end{array}$ & $\begin{array}{l}1.60 \\
(132)\end{array}$ & $\begin{array}{l}11.9 \\
(335)\end{array}$ & $\begin{array}{l}0.50 \\
(8.2)\end{array}$ & $\begin{array}{l}0.081 \\
(1.69)\end{array}$ & $(345)$ & 18.8 & 22.2 & 8.03 & & & 1.0134 \\
\hline 6 & 3 & 55.4 & $\begin{array}{l}4.83 \\
(210)\end{array}$ & $\begin{array}{l}0.219 \\
(5.60)\end{array}$ & $\begin{array}{l}0.05 \\
(3.0)\end{array}$ & $\begin{array}{l}1.37 \\
(68.2)\end{array}$ & $\begin{array}{l}2.24 \\
(185)\end{array}$ & $\begin{array}{l}16.7 \\
(472)\end{array}$ & $\begin{array}{l}0.23 \\
(3.7)\end{array}$ & $\begin{array}{l}0.067 \\
(1.39)\end{array}$ & $(477)$ & 25.7 & 30.6 & 7.04 & & $\begin{array}{l}47.8 \\
(811)\end{array}$ & 1.0188 \\
\hline 9 & 1 & 77.4 & & & & $\begin{array}{l}2.20 \\
(110)\end{array}$ & $\begin{array}{l}2.21^{*} \\
(182)\end{array}$ & $\begin{array}{l}22.3^{*} \\
(629)\end{array}$ & $\begin{array}{l}0.331 \\
(5.41)\end{array}$ & & & & 40.2 & 7.23 & 30 & & 1.0258 \\
\hline 10 & 3 & 92.0 & $\begin{array}{l}7.15 \\
(311)\end{array}$ & $\begin{array}{l}0.140 \\
(3.58)\end{array}$ & $\begin{array}{l}0.116 \\
(6.41)\end{array}$ & $\begin{array}{l}1.99 \\
(99.1)\end{array}$ & $\begin{array}{l}2.02 \\
(166)\end{array}$ & $\begin{array}{l}20.3 \\
(573)\end{array}$ & $\begin{array}{l}0.41 \\
(6.8)\end{array}$ & $\begin{array}{l}0.291 \\
(6.06)\end{array}$ & (586) & 32.4 & 36.7 & 7.05 & 28 & & 1.0222 \\
\hline 12 & 3 & D9.5 & & & & $\begin{array}{l}1.98 \\
(98.6)\end{array}$ & & & & & & & 41.0 & & 29 & & \\
\hline 14 & 5 & 133.5 & $\begin{array}{l}9.15 \\
(398)\end{array}$ & $\begin{array}{l}0.189 \\
(4.82)\end{array}$ & $\begin{array}{l}0.121 \\
(6.72)\end{array}$ & $\begin{array}{l}2.34 \\
(117)\end{array}$ & $\begin{array}{l}2.26 \\
(186)\end{array}$ & $\begin{array}{l}25.0 \\
(705)\end{array}$ & $\begin{array}{l}0.17 \\
(2.8)\end{array}$ & $\begin{array}{l}0.253 \\
(5.27)\end{array}$ & (713) & 39.5 & 45.9 & 6.89 & & $\begin{array}{l}17.2 \\
(295)\end{array}$ & 1.0297 \\
\hline 15 & 2 & 136.4 & & & & $\begin{array}{l}2.08 \\
(104)\end{array}$ & & & $\begin{array}{l}0.24 \\
(3.9)\end{array}$ & & & & 41.2 & 7.30 & & & 1.0264 \\
\hline 17 & 2 & 166 & $\begin{array}{l}10.6 \\
(462)\end{array}$ & $\begin{array}{l}0.209 \\
(5.34)\end{array}$ & $\begin{array}{l}0.12 \\
(6.7)\end{array}$ & $\begin{array}{l}2.71 \\
(135)\end{array}$ & $\begin{array}{l}2.32 \\
(191)\end{array}$ & $\begin{array}{l}28.1 \\
(793)\end{array}$ & $\begin{array}{l}0.12 \\
(2.0)\end{array}$ & $\begin{array}{l}0.243 \\
(5.06)\end{array}$ & $(800)$ & 44.5 & 50.9 & 7.08 & 25 & $\begin{array}{l}31.7 \\
(545)\end{array}$ & 1.0324 \\
\hline 19 & 5 & 179.9 & contan & lation & & & & & & & & & & & & & \\
\hline 21 & 3 & 194.9 & $\begin{array}{l}10.4 \\
(453)\end{array}$ & $\begin{array}{l}0.169 \\
(4.33)\end{array}$ & $\begin{array}{l}0.120 \\
(6.67)\end{array}$ & $\begin{array}{l}2.52 \\
(126)\end{array}$ & $\begin{array}{l}2.33 \\
(192)\end{array}$ & $\begin{array}{l}27.2 \\
(767)\end{array}$ & $\begin{array}{l}0.38 \\
(6.3)\end{array}$ & $\begin{array}{l}0.439 \\
(9.14)\end{array}$ & (782) & 43.6 & 49.1 & 7.4 & 23 & $\begin{array}{r}9.95 \\
(171)\end{array}$ & 1.031 \\
\hline 23 & 6 & 216.9 & $\begin{array}{l}11.2 \\
(487)\end{array}$ & $\begin{array}{l}0.106 \\
(2.72)\end{array}$ & $\begin{array}{l}0.12 \\
(6.7)\end{array}$ & $\begin{array}{l}3.11 \\
(155)\end{array}$ & $\begin{array}{l}3.02 \\
(249)\end{array}$ & $\begin{array}{l}31.8 \\
(898)\end{array}$ & $\begin{array}{l}0.13 \\
(2.2)\end{array}$ & $\begin{array}{l}0.023 \\
(0.49)\end{array}$ & (901) & 49.5 & 57.7 & 7.2 & 22 & & 1.0373 \\
\hline 25 & 3 & 232.8 & & & & $\begin{array}{l}1.72 \\
(86.0)\end{array}$ & & & $\begin{array}{l}0.149 \\
(2.44)\end{array}$ & & & & 40.7 & 7.08 & & & 1.0261 \\
\hline 27 & 3 & 245.5 & 12.1 & 0.123 & 0.121 & 2.56 & 3.24 & 32.9 & 0.15 & 0.126 & & 51.3 & 58.0 & & & 5.17 & 1.0377 \\
\hline 29 & 1 & 273.9 & & & & $\begin{array}{l}2.32 \\
(116)\end{array}$ & $\begin{array}{l}2.80 * \\
(230)\end{array}$ & $\begin{array}{l}33.1 * \\
(934)\end{array}$ & $\begin{array}{l}0.728 \\
(11.9)\end{array}$ & & & & 58.3 & 7.15 & 21 & & .0374 \\
\hline 31 & 1 & 292.9 & $\begin{array}{l}14.8 \\
(643)\end{array}$ & $\begin{array}{l}0.264 \\
(6.74)\end{array}$ & $\begin{array}{l}0.165 \\
(9.12)\end{array}$ & $\begin{array}{l}2.36 \\
(118)\end{array}$ & $\begin{array}{l}2.62 \\
(216)\end{array}$ & $\begin{array}{l}34.9 \\
(984)\end{array}$ & $\begin{array}{l}0.39 \\
(6.4)\end{array}$ & $\begin{array}{l}0.102 \\
(2.12)\end{array}$ & (992) & 55.5 & 61.4 & 7.0 & 21 & $\begin{array}{l}23.2 \\
(401)\end{array}$ & 1.0390 \\
\hline 33 & 3 & 309.9 & & & & $\begin{array}{l}2.36 \\
(118)\end{array}$ & $\begin{array}{l}2.26 * \\
(186)\end{array}$ & $\begin{array}{l}34.6^{*} \\
(876)\end{array}$ & $\begin{array}{l}0.716 \\
(11.7)\end{array}$ & & & & 62.2 & 7.09 & 22 & & 1.0399 \\
\hline 35 & 3 & 318.5 & $\begin{array}{l}17.0 \\
(740)\end{array}$ & $\begin{array}{l}0.204 \\
(5.21)\end{array}$ & $\begin{array}{l}0.14 \\
(7.7)\end{array}$ & $\begin{array}{l}2.36 \\
(118)\end{array}$ & $\begin{array}{l}2.03 \\
(167)\end{array}$ & $\begin{array}{l}36.6 \\
(1031)\end{array}$ & $\begin{array}{l}0.32 \\
(5.2)\end{array}$ & $\begin{array}{l}0.073 \\
(1.52)\end{array}$ & (1038) & 58.7 & 62.9 & $\begin{array}{l}7.15 \\
6.99\end{array}$ & 26 & & 1.0413 \\
\hline 37 & 1 & 342.5 & & & & $\begin{array}{l}2.28 \\
(114)\end{array}$ & $\begin{array}{l}1.90^{*} \\
(156)\end{array}$ & $\begin{array}{l}36.8^{*} \\
(1038)\end{array}$ & $\begin{array}{l}0.241 \\
(3.94)\end{array}$ & & & & 63.8 & & 26 & & 1.0409 \\
\hline 39 & 5 & 365 & $\begin{array}{l}19.4 \\
(843)\end{array}$ & $\begin{array}{l}0.107 \\
(2.74)\end{array}$ & $\begin{array}{l}0.115 \\
(6.26)\end{array}$ & $\begin{array}{l}2.10 \\
(105)\end{array}$ & $\begin{array}{l}1.60 \\
(132)\end{array}$ & $\begin{array}{l}38.5 \\
(1085)\end{array}$ & $\begin{array}{l}0.23 \\
(3.7)\end{array}$ & $\begin{array}{l}0.029 \\
(0.61)\end{array}$ & (1089) & 62.1 & 65.6 & 7.95 & 34 & $\begin{array}{l}39.5 \\
(684)\end{array}$ & 1.0423 \\
\hline
\end{tabular}




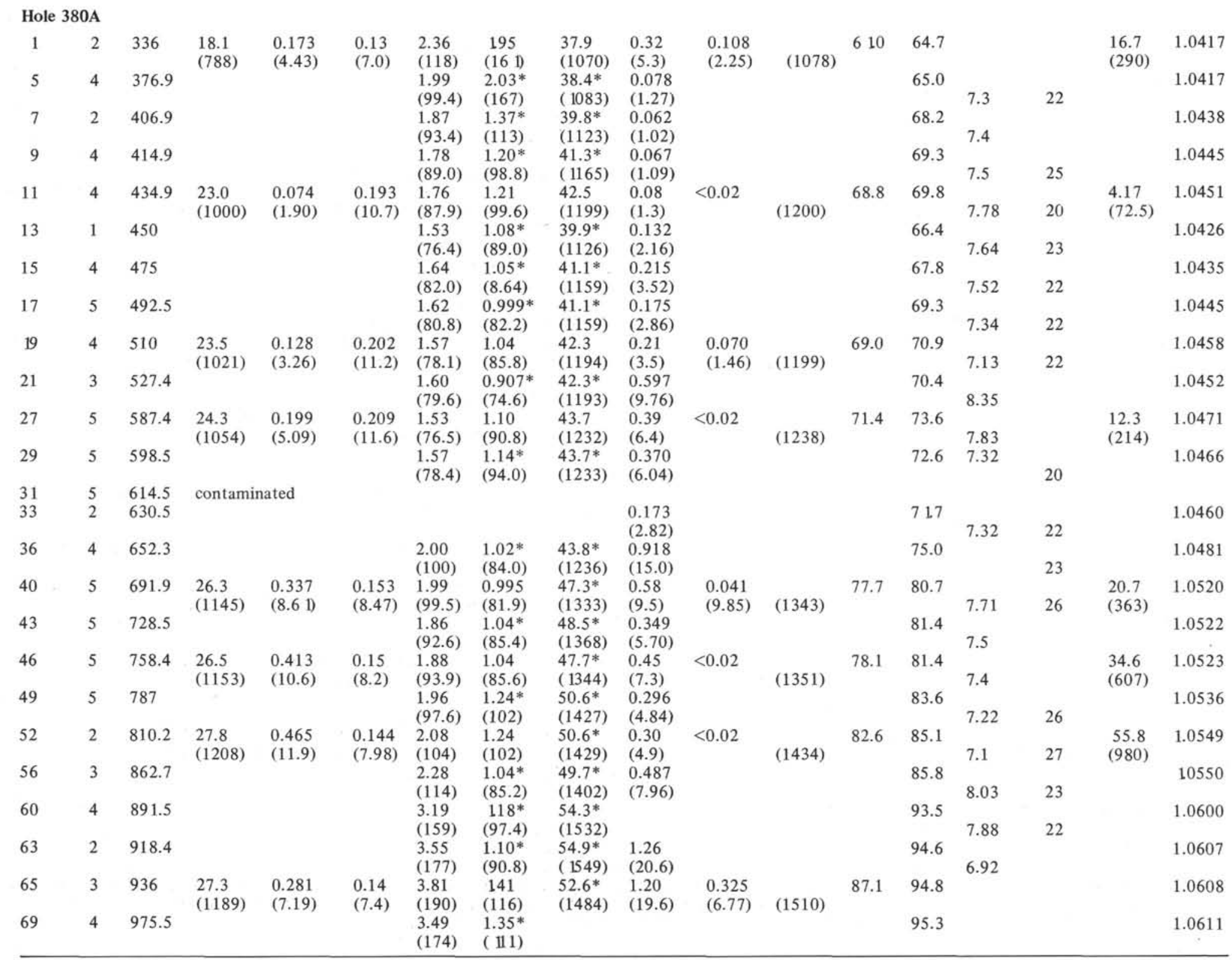

Note: See Table 2 for explanation. 
TABLE 4

Interstitial Water Data for Site 381

\begin{tabular}{|c|c|c|c|c|c|c|c|c|c|c|c|c|c|c|c|c|c|}
\hline Core & $\mathrm{Sec}$ & $\begin{array}{c}\text { Depth } \\
\text { (m) }\end{array}$ & $\mathrm{Na}$ & K & $\mathrm{NH}_{4}$ & $\mathrm{Ca}$ & $\mathrm{Mg}$ & $\mathrm{Cl}$ & $\begin{array}{l}\mathrm{HCO}_{3} \\
\mathrm{AKL}\end{array}$ & $\mathrm{SO}_{4}$ & $\mathrm{C}_{\mathrm{A}}$ & $\mathrm{C}_{\mathrm{S}}$ & Sal & $p \mathrm{H}$ & $\mathrm{H}_{2} \mathrm{O}(\%)$ & $\mathrm{SiO}_{2}$ & $\mathrm{D} 25^{\circ} \mathrm{C}$ \\
\hline \multicolumn{2}{|c|}{ Surface site } & & & & & $\begin{array}{l}0.256 \\
(12.8)\end{array}$ & $\begin{array}{l}0.744^{*} \\
(61.2)\end{array}$ & $\begin{array}{l}10.3^{*} \\
(291)\end{array}$ & $\begin{array}{l}0.284 \\
(4.64)\end{array}$ & & & & 18.7 & \multirow[t]{2}{*}{8.62} & & & 1.0127 \\
\hline 1 & 1 & 0.3 & $\begin{array}{l}7.19 \\
(313)\end{array}$ & $\begin{array}{l}0.282 \\
(7.22)\end{array}$ & $<0.01$ & $\begin{array}{l}0.319 \\
(15.9)\end{array}$ & $\begin{array}{l}0.802 \\
(66.0)\end{array}$ & $\begin{array}{l}12.5 \\
(351)\end{array}$ & $\begin{array}{l}1.1 \\
\text { (18) }\end{array}$ & $\begin{array}{l}1.59 \\
(33.0)\end{array}$ & (402) & 23.8 & 22.8 & & & & 1.0153 \\
\hline 1 & 2 & 3.0 & $\begin{array}{l}8.49 \\
(369)\end{array}$ & $\begin{array}{l}0.184 \\
(4.71)\end{array}$ & $\begin{array}{l}0.050 \\
(2.77)\end{array}$ & $\begin{array}{l}0.625 \\
(31.2)\end{array}$ & $\begin{array}{l}0.778 \\
(64.0)\end{array}$ & $\begin{array}{l}15.7 \\
(444)\end{array}$ & $\begin{array}{l}1.10 \\
(18.1)\end{array}$ & $\begin{array}{l}0.460 \\
(9.58)\end{array}$ & (472) & 27.4 & 26.9 & 7.33 & & $\begin{array}{l}36.2 \\
(613)\end{array}$ & 10183 \\
\hline 2 & 2 & 17.4 & $\begin{array}{l}8.52 \\
(371)\end{array}$ & $\begin{array}{l}0.160 \\
(4.09)\end{array}$ & $\begin{array}{l}0.041 \\
(2.29)\end{array}$ & $\begin{array}{l}0.749 \\
(37.4)\end{array}$ & $\begin{array}{l}0.750 \\
(61.7)\end{array}$ & $\begin{array}{l}16.2 \\
(458)\end{array}$ & $\begin{array}{l}1.06 \\
(17.4)\end{array}$ & $\begin{array}{l}0.028 \\
(0.59)\end{array}$ & (476) & 27.5 & 27.7 & 7.44 & & & 1.0173 \\
\hline 3 & 3 & 27.0 & $\begin{array}{l}12.5 \\
(542)\end{array}$ & $\begin{array}{l}0.067 \\
(1.72)\end{array}$ & $\begin{array}{l}0.072 \\
(4.01)\end{array}$ & $\begin{array}{l}1.29 \\
(64.3)\end{array}$ & $\begin{array}{l}0.854 \\
(70.2)\end{array}$ & $\begin{array}{l}23.5 \\
(664)\end{array}$ & $\begin{array}{l}1.09 \\
(17.8)\end{array}$ & $\begin{array}{l}0.020 \\
(0.42)\end{array}$ & (682) & 39.4 & & 7.75 & & $\begin{array}{l}10.7 \\
(182)\end{array}$ & 1.0272 \\
\hline 5 & 2 & 43.0 & $\begin{array}{l}18.7 \\
(813)\end{array}$ & $\begin{array}{l}0.069 \\
(1.76)\end{array}$ & $\begin{array}{l}0.091 \\
(5.06)\end{array}$ & $\begin{array}{l}1.60 \\
(79.7)\end{array}$ & $\begin{array}{l}0.981 \\
(80.7)\end{array}$ & $\begin{array}{l}34.5 \\
(972)\end{array}$ & $\begin{array}{l}0.47 \\
(7.7)\end{array}$ & $\begin{array}{l}0.004 \\
(0.09)\end{array}$ & (980) & 56.4 & 57.0 & 7.51 & & & 1.0394 \\
\hline 7 & 5 & 65.0 & $\begin{array}{l}19.8 \\
(863)\end{array}$ & $\begin{array}{l}0.061 \\
(1.56)\end{array}$ & $\begin{array}{l}0.100 \\
(5.54)\end{array}$ & $\begin{array}{l}1.54 \\
(76.6)\end{array}$ & $\begin{array}{l}0.950 \\
(78.1)\end{array}$ & $\begin{array}{l}36.0 \\
(1016)\end{array}$ & $\begin{array}{l}0.43 \\
(7.0)\end{array}$ & $\begin{array}{l}0.086 \\
(180)\end{array}$ & ( D25) & 59.0 & 59.6 & 7.34 & & & 1.0407 \\
\hline 9 & 5 & 84.0 & & & & $\begin{array}{l}1.63 \\
(81.2)\end{array}$ & $\begin{array}{l}1.13^{*} \\
(92.8)\end{array}$ & $\begin{array}{l}38.6^{*} \\
(1089)\end{array}$ & $\begin{array}{l}0.44 \\
(7.2)\end{array}$ & & & & 64.4 & & 8.05 & & 1.0439 \\
\hline 14 & 5 & $\begin{array}{l}111 \\
133\end{array}$ & Contan & nated & & $\begin{array}{l}1.51 \\
(75.4)\end{array}$ & $\begin{array}{l}1.03^{*} \\
(85.0)\end{array}$ & $\begin{array}{l}35.6^{*} \\
(1004)\end{array}$ & $\begin{array}{l}0.430 \\
(7.02)\end{array}$ & & & & 59.4 & & 7.75 & & 1.0405 \\
\hline 16 & 5 & 152 & $\begin{array}{l}20.7 \\
(900)\end{array}$ & $\begin{array}{l}0.140 \\
(3.57)\end{array}$ & $\begin{array}{l}0.125 \\
(6.91)\end{array}$ & $\begin{array}{l}1.70 \\
(84.7)\end{array}$ & $\begin{array}{l}0.955 \\
(78.6)\end{array}$ & $\begin{array}{l}37.7 \\
(1065)\end{array}$ & $\begin{array}{l}0.49 \\
(8.0)\end{array}$ & $\begin{array}{l}0.076 \\
(1.58)\end{array}$ & (1075) & 61.9 & 63.1 & 7.01 & & $\begin{array}{l}10.7 \\
(186)\end{array}$ & 1.0433 \\
\hline 18 & 5 & $\begin{array}{l}171 \\
176.5\end{array}$ & & & & $\begin{array}{l}1.56 \\
(77.6)\end{array}$ & $\begin{array}{l}0.931^{*} \\
(76.6)\end{array}$ & $\begin{array}{l}32.8^{*} \\
(925)\end{array}$ & $\begin{array}{l}0.35 \\
(5.8) \\
0.29\end{array}$ & & & & 54.1 & & 7.51 & & 1.0369 \\
\hline 19 & 4 & 176.5 & & & & $\begin{array}{l}1.90 \\
(94.8)\end{array}$ & $\begin{array}{l}1.30^{*} \\
(107)\end{array}$ & $\begin{array}{l}37.7 * \\
(1063)\end{array}$ & $\begin{array}{l}0.29 \\
(4.7)\end{array}$ & & & & 63.8 & & & & 1.0435 \\
\hline 23 & Top & 209 & $\begin{array}{l}20.3 \\
(881)\end{array}$ & $\begin{array}{l}0.163 \\
(4.16)\end{array}$ & $\begin{array}{l}0.13 \\
(7.3)\end{array}$ & $\begin{array}{l}2.04 \\
(102) \\
1.94\end{array}$ & $\begin{array}{l}1.03 \\
(85.0) \\
1.00^{*}\end{array}$ & $\begin{array}{l}37.7 \\
(1064) \\
37.7^{*}\end{array}$ & $\begin{array}{l}0.37 \\
(6.0) \\
0.48\end{array}$ & $\begin{array}{l}0.041 \\
(0.852)\end{array}$ & (1079) & 61.8 & 64.1 & & & & 1.0433 \\
\hline 27 & 2 & $\begin{array}{l}225 \\
244\end{array}$ & & & & $\begin{array}{l}1.94 \\
(97.0) \\
1.98\end{array}$ & $\begin{array}{l}1.00^{*} \\
(82.4) \\
0.977^{*}\end{array}$ & $\begin{array}{l}37.7^{*} \\
(1063) \\
38.4^{*}\end{array}$ & $\begin{array}{l}0.48 \\
(7.9) \\
0.57\end{array}$ & & & & 64.9 & & 7.58 & & 1.0443 \\
\hline 29 & 5 & 264.5 & 21.4 & 0.189 & 0.14 & $\begin{array}{l}(98.8) \\
1.83\end{array}$ & $\begin{array}{l}(80.4) \\
1.03\end{array}$ & & $\begin{array}{l}(9.3) \\
0.29\end{array}$ & 0.222 & & 64.6 & $\begin{array}{l}66.6 \\
64.9\end{array}$ & & 7.48 & 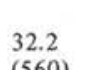 & $\begin{array}{l}1.0454 \\
1.0444\end{array}$ \\
\hline 31 & 4 & 282 & 0332 & $(4.83)$ & 0778 & $\begin{array}{l}(91.3) \\
1.94 \\
(97.0)\end{array}$ & $\begin{array}{l}(84.8) \\
1.05^{*} \\
(86.6)\end{array}$ & $\begin{array}{l}(1113) \\
39.4^{*} \\
(1111)\end{array}$ & $\begin{array}{l}(4.7) \\
0.574 \\
(9.38)\end{array}$ & (4. & (1122) & & 66.0 & 7.10 & 7.45 & & 1.0450 \\
\hline 33 & 4 & 301 & & & & $\begin{array}{l}1.83 \\
(91.4)\end{array}$ & $\begin{array}{l}1.35^{*} \\
\text { (11) }\end{array}$ & $\begin{array}{l}38.7^{*} \\
(1092)\end{array}$ & $\begin{array}{l}0.452 \\
(7.38)\end{array}$ & & & & 64.4 & & 7.0 & & 1.04 \\
\hline 35 & 5 & 321.5 & $\begin{array}{l}214 \\
(929)\end{array}$ & $\begin{array}{l}0.181 \\
(4.63)\end{array}$ & $\begin{array}{l}0.193 \\
(10.7)\end{array}$ & $\begin{array}{l}1.85 \\
(92.3)\end{array}$ & $\begin{array}{c}102 \\
(84.0)\end{array}$ & $\begin{array}{l}39.4 \\
\text { (11 } 10)\end{array}$ & $\begin{array}{l}0.45 \\
(7.3)\end{array}$ & $\begin{array}{l}0.165 \\
(3.44)\end{array}$ & (1121) & 64.7 & 65.9 & 7.05 & & $\begin{array}{l}48.9 \\
(853)\end{array}$ & 1.0466 \\
\hline 37 & 2 & 336 & & & & $\begin{array}{l}1.68 \\
(83.8)\end{array}$ & $\begin{array}{l}1.08^{*} \\
(89.0)\end{array}$ & $\begin{array}{l}40.1^{*} \\
(1131)\end{array}$ & $\begin{array}{l}0.223 \\
(3.64)\end{array}$ & & & & 64.8 & & 6.92 & & 1.0442 \\
\hline 42 & 1 & 399 & 20 & & 0 & $\begin{array}{l}1.30 \\
(64.8)\end{array}$ & $\begin{array}{l}0.943^{*} \\
(77.6)\end{array}$ & $\begin{array}{l}32.8^{*} \\
(925)\end{array}$ & $\begin{array}{l}0.222 \\
(3.62)\end{array}$ & & & & 54.5 & & 7.49 & & 103 \\
\hline 48 & 5 & 445 & $\begin{array}{l}13.9 \\
(606)\end{array}$ & $\begin{array}{l}0.123 \\
(3.13)\end{array}$ & $\begin{array}{l}0.088 \\
(4.85)\end{array}$ & $\begin{array}{l}0.961 \\
(48.0)\end{array}$ & $\begin{array}{l}0.862 \\
(70.9)\end{array}$ & $\begin{array}{l}25.2 \\
(718)\end{array}$ & $\begin{array}{l}0.82 \\
(13.4)\end{array}$ & $\begin{array}{l}0.103 \\
(2.14)\end{array}$ & (733) & 42.1 & 41.6 & 8.62 & & $\begin{array}{l}10.2 \\
(175)\end{array}$ & 1.0299 \\
\hline 51 & 4 & 472 & $\begin{array}{l}12.5 \\
(543)\end{array}$ & $\begin{array}{l}0.121 \\
(3.12)\end{array}$ & $\begin{array}{l}0.075 \\
(4.17)\end{array}$ & $\begin{array}{l}0.900 \\
(44.9)\end{array}$ & $\begin{array}{l}0.956 \\
(78.6)\end{array}$ & $\begin{array}{l}23.8^{*} \\
(669)\end{array}$ & $\begin{array}{l}0.33 \\
(5.4)\end{array}$ & $\begin{array}{c}<0.03 \\
(0.06)\end{array}$ & (674) & 38.7 & 39.0 & 8.07 & & & 1.0328 \\
\hline 53 & 2 & 492.4 & & & & $\begin{array}{l}0.882 \\
(440)\end{array}$ & $\begin{array}{l}0.878^{*} \\
(72.2)\end{array}$ & $\begin{array}{l}23.5^{*} \\
(663)\end{array}$ & $\begin{array}{l}0.31 \\
(5.1)\end{array}$ & & & & & 8.00 & & & 1.0263 \\
\hline 54 & 4 & 502 & $\begin{array}{l}11.3 \\
(493)\end{array}$ & $\begin{array}{l}0.089 \\
(2.28)\end{array}$ & $\begin{array}{l}0.06 \\
(3.5)\end{array}$ & $\begin{array}{l}0.868 \\
(43.3)\end{array}$ & $\begin{array}{l}0.776 \\
(63.8)\end{array}$ & $\begin{array}{l}21.3 \\
\text { (599) }\end{array}$ & $\begin{array}{l}0.38 \\
(6.2)\end{array}$ & $\begin{array}{l}0.030 \\
(0.62)\end{array}$ & (606) & 34.8 & 35.4 & 8.13 & & & 1.0252 \\
\hline
\end{tabular}

Note: See Table 2 for explanation.

TABLE 5

Comparison of Composition of Surface Black Sea Waters for Sites 379, 380, and Data of Russian Authors (Skopintsev, 1958)

\begin{tabular}{lccccccccccc}
\hline Hole & $\mathrm{Na}$ & $\mathrm{K}$ & $\mathrm{Ca}$ & $\mathrm{Mg}$ & $\mathrm{SO}_{4}$ & $\mathrm{C} 1$ & $\begin{array}{l}\mathrm{Na} \\
\mathrm{C} 1\end{array}$ & $\begin{array}{l}\mathrm{K} \\
\mathrm{C} 1\end{array}$ & $\begin{array}{l}\mathrm{Ca} \\
\mathrm{C} 1\end{array}$ & $\begin{array}{l}\mathrm{Mg} \\
\mathrm{SO}_{4}\end{array}$ & $\begin{array}{l}\mathrm{SO}_{4} \\
\mathrm{C}^{4}\end{array}$ \\
\hline 379 & 5.33 & 0.196 & 0.249 & 0.656 & 1.34 & 9.65 & 0.552 & 0.203 & 0.258 & 0.680 & 0.138 \\
Russ. $^{\text {a }}$ & 5.52 & 0.212 & 0.248 & 0.686 & 1.35 & 10.03 & 0.552 & 0.212 & 0.248 & 0.686 & 0.135 \\
\hline
\end{tabular}

Note: Current data are from shore laboratory results; except Ca which includes Sr. C1 includes Br. Units are in $\mathrm{g} / \mathrm{kg}$.

${ }^{\mathrm{a}}$ Mean of five samples.

less saline waters would also be found. The higher salinities found at Site 380 are explained not by variable salinity in different parts of the Black Sea during the hypersaline period, but probably to the rapid deposition of sediments during the saline period and downward penetration of salt during the episode(s), thus forming a buffer supply of salt against later diffusive leaching. 


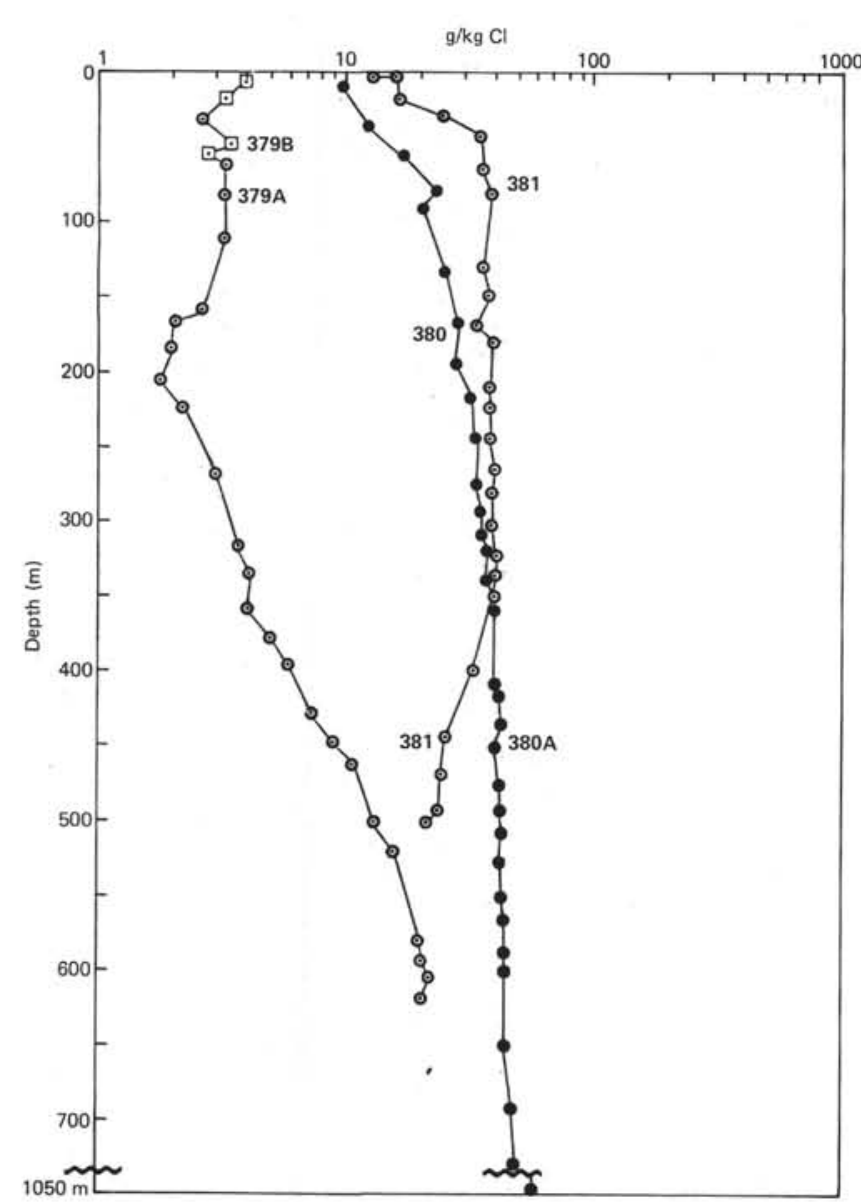

Figure 4. Distribution of interstitial chloride with depth in Sites 379, 380, and 381. Values are in $\mathrm{g} / \mathrm{kg}$.

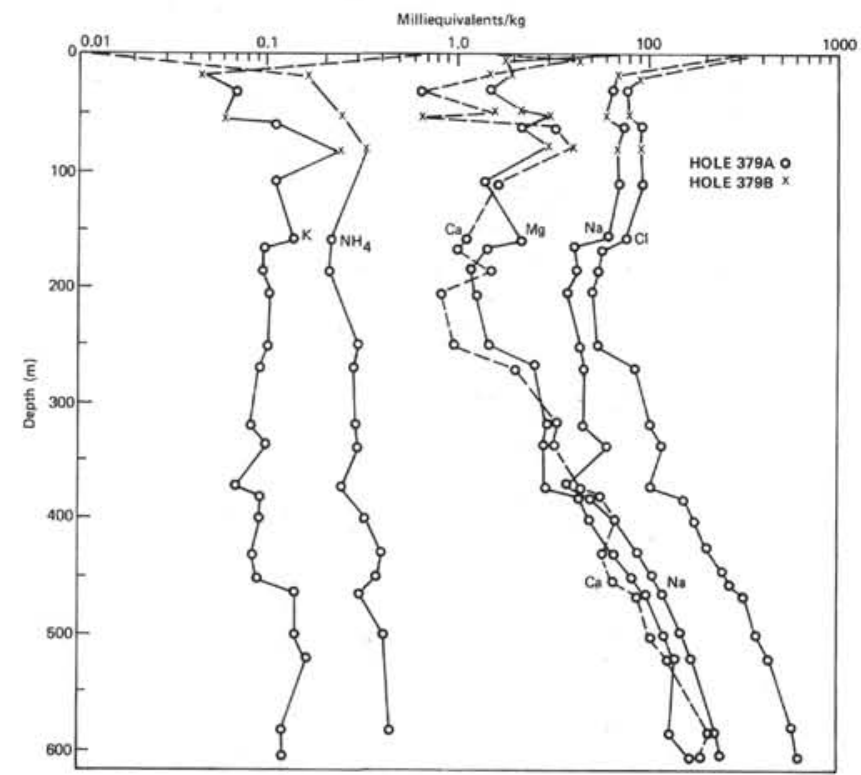

Figure 5. Distribution of major ions in interstitial waters with depth in Holes $379 \mathrm{~A}$ and $379 B$. Values are in milliequivalents $/ \mathrm{kg}$.

The age and stratigraphic delineation of the hypersaline episode is not complete at this writing. However, we can establish such development occurred

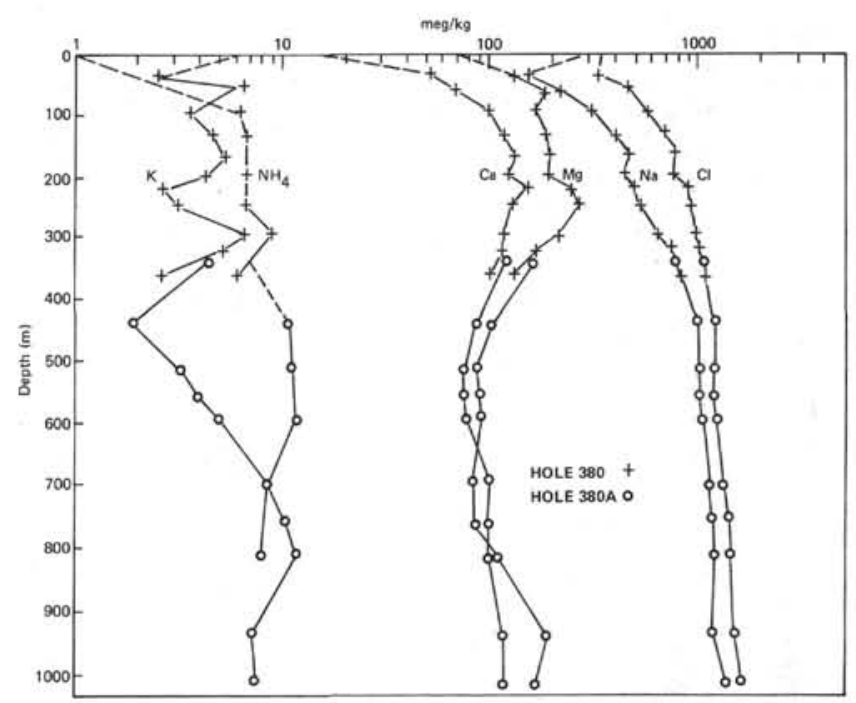

Figure 6. Distribution of major ions in interstitial waters with depth, Holes 380 and 380A. Values are in milliequivalents $/ \mathrm{kg}$.

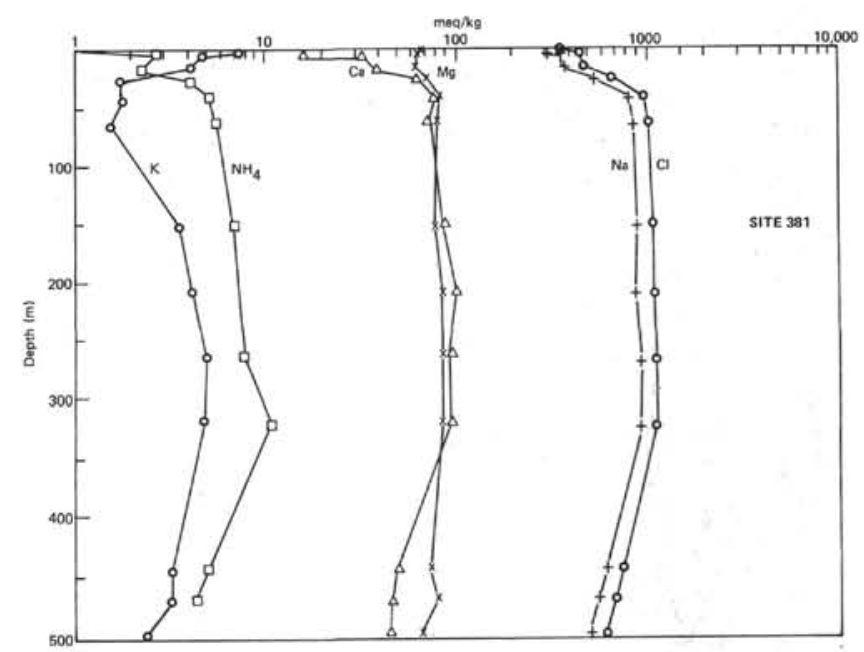

Figure 7. Distribution of major ions in interstitial waters with depth, Site 381. Values are in milliequivalents/kg.

no later than Jousé and Mukhina's Mindel-Riss (Figure 8 ), and occurred not long before the major break in the salinity and especially $\mathrm{Ca}-\mathrm{Mg}$ curves (Figures 5-7). That this took place as high as 38 meters below sea floor at Site 381 confirms the concept that either a hiatus or significant erosion has taken place in this area. This in turn explains the interstitial salinity high in this part of the Black Sea, based on mapping of earlier pore fluid data (Figure 2). By inference, this map permits localization of erosion or hiatus zones in the formation of post-Mindel-Riss sediments.

\section{Regional (Caspian) Relationships}

Comparative study of interstitial waters is available from a series of drill cores in the shallow western Caspi n Sea (Pushkina, 1965). Figure 9 is modified from this work. As noted under Methods, we believe that the sawtooth pattern for chemical constituents may be partly a function of contamination with drilling 


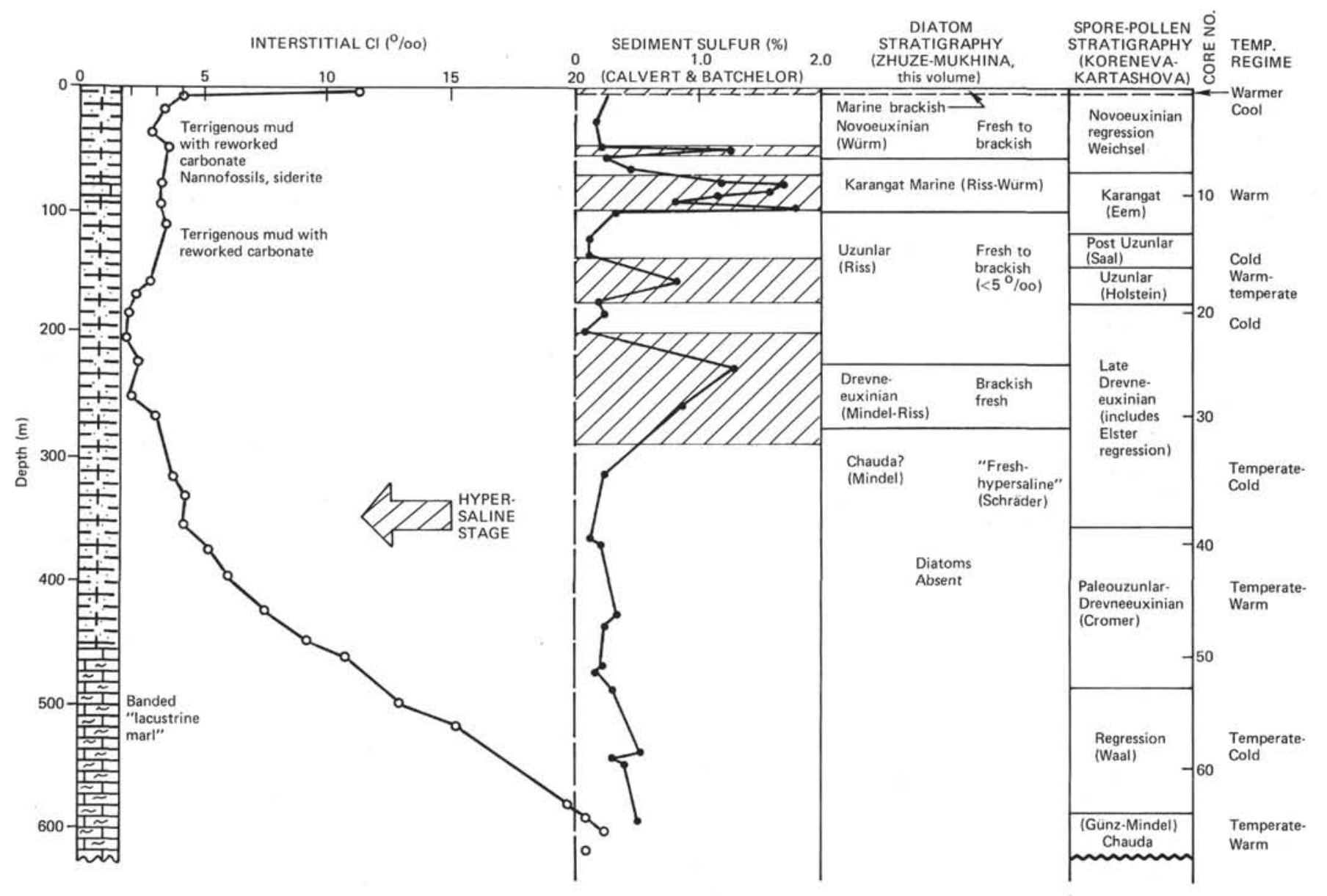

Figure 8. Distribution of interstitial chlorinity and other environmentally related parameters for Holes 379 and $379 \mathrm{~A}$. The shaded intervals are slightly modified from Calvert and Batchelor and are zones interpreted as having significantly marine character, based on sediment sulfur concentrations. The arrow refers to approximate upper extent of influence of hypersaline phase of Black Sea on present-day interstitial waters. Note that diffusion has probably shifted the saline boundaries downward. Stratigraphic intervals are simplifications of other stratigraphic determinations, particularly with regard to diatom stratigraphy determined by Zhuze and Mukhina (this volume).

fluid; hence the corrected curves may resemble to an even greater degree the pattern of interstitial fluids found at Sites 380 and 381 . They suggest that hypersaline conditions in the Caspian may have been not unlike those in the Black Sea during Plio-Pleistocene time, and that no Miocene evaporites are present in this part of the Caspian. The evidence of gypsum in the cores suggests a higher level of development of hypersalinity, but the possibility that some of the gypsum may be the result of artifacts on storage of the cores cannot be excluded, since such effects can easily be observed even in cores from waters of normal marine salinity (especially in pyrite-rich zones). Thus both Black Sea and Caspian Sea do not appear on current evidence to have had upper Miocene salt deposits, unlike the Mediterranean. Mulder et al. (1975) show presence of Miocene salt deposits in the Black Sea, but no evidence for such development is cited.

Shishkina (this volume) indicates that $\mathrm{Cl} / \mathrm{Br}$ ratios of $>300$ in interstitial waters of Holes 380/380A suggest that leaching of $\mathrm{NaCl}$ (halite) precipitates has occurred. This conclusion is drawn from the fact that early precipitates of $\mathrm{NaCl}$ in seawater are depleted in $\mathrm{Br}$ with respect to seawater $\mathrm{Cl} / \mathrm{Br}$ ratios. On the other hand, modest decrease in the interstitial $\mathrm{Cl} / \mathrm{Br}$ ratios may reflect decomposition of organic matter with addition of $\mathrm{Br}$ to pore fluids. Since neither halite nor gypsum/anhydrite were observed in the cores, nor do the interstitial brines approach saturation with halite, we conclude either the halite was deposited locally and redissolved at early stages of basin development, or the brines incorporated in the sediments migrated into their locations (deeper basin) from areas where such salt dissolution was taking place. A model for this type of development would be major expansion of some of the current hypersaline limans (brine lakes) along the northern present margin of the Black Sea and Sea of Azov (e.g., Kuyalnitskii liman, Odessa; Sivash, Sea of Azov). In such a model, heavier brines might move by gravitational convection from the coastal areas into the deeps. This would require mixing of the $\mathrm{Br}$-enriched evaporative mother liquors with Black Sea waters at other times and loss from the system.

\section{Diagenesis and Rock-Water Interactions}

Figure 6 (Site 380) provides a good overview for the reactions of cations in the pore fluids. It can be seen 


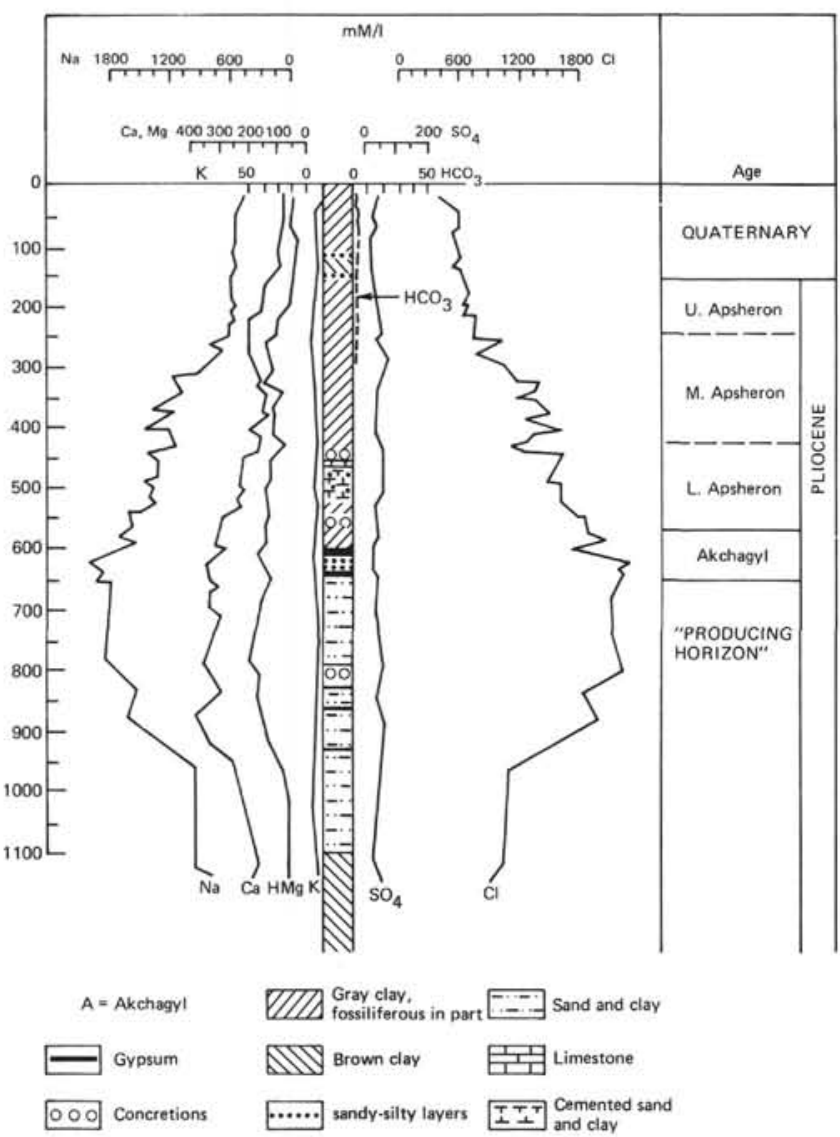

Figure 9. Distribution of ions in pore fluids of Borehole No. 4, off Baku, Caspian Sea. Values in milliequivalents/ liter. Modified from Pushkina (1965) and Daidbekova et al. (1965).

from the distance between the $\mathrm{Na}$ and $\mathrm{Cl}$ curves that, as $\mathrm{Ca}$ and $\mathrm{Mg}$ increase markedly from 40 to 300 meters, there is a relative loss of $\mathrm{Na}$ with respect to $\mathrm{Ca}$. On a semi-log plot of this type constant horizontal distance represents constant ratios, no matter what concentration is involved. On the other hand, the increase in $\mathrm{Ca}$ and $\mathrm{Mg}$ near the bottom of the hole occurs without comparable loss in $\mathrm{Na}$. We interpret the first type of reaction as involving uptake on $\mathrm{Na}$ in silicate materials, liberating $\mathrm{Ca}$ or other cations to balance the $\mathrm{Cl}$ thus made available:

$$
2(\mathrm{Na}, \mathrm{K}) \mathrm{Cl}+\mathrm{CaSiO}_{3}=(\mathrm{Na}, \mathrm{K})_{2} \mathrm{SiO}_{3}+\mathrm{CaCl}_{2}
$$

$\mathrm{Ca}$ silicates may be available in volcanic ash, and the sodium-potassium silicate is a representative of possible clay mineral synthesis. Similar reactions have been suggested by Shishkina (1969) based on evidence in lower sections of piston cores. On the other hand, at the base of the section a dolomitization reaction may account for the high $\mathrm{Ca}$ and preponderance over $\mathrm{Mg}$, with little loss of $\mathrm{Na}$ :

$$
\mathrm{MgCl}_{2}+2 \mathrm{CaCO}_{3}=\mathrm{CaCl}_{2}+\mathrm{MgCa}\left(\mathrm{CO}_{3}\right)_{2}
$$

A more pronounced silicate diagenesis situation appears at Site 379 , where $\mathrm{Ca}$ and $\mathrm{Mg}$ values nearly equal $\mathrm{Na}$ concentrations in the pore fluid. $\mathrm{Mg}$ concentrations can be explained by evaporitic enrichment in a playa basin, but, to obtain $\mathrm{CaCl}_{2}$, exchange reactions of $\mathrm{MgCl}_{2}$ or $\mathrm{NaCl}_{2}$ with $\mathrm{Ca}$ containing phases must be invoked.

Where purely diagenetic reactions are involved, $\mathrm{Ca}$ and $\mathrm{Mg}$ tend to be related inversely, whereas increments of evaporitically enriched soluble elements of seawater may cause $\mathrm{Ca}$ and $\mathrm{Mg}$ to "track" as at Site 381. In all cases below the surficial sediments, $\mathrm{SO}_{4}$ appears to have been lost from the system via sulfate reduction. Data of King and White (this volume) indicate that the bacterial activity is low in the deeper sediments; it is nevertheless finite and may be ascribed, at least in part, to methane production. The small residual sulfate values are believed to be attributed to minor oxidation of sulfides during shipboard manipulation of sediments and squeezing. Similar values were obtained in sediments below a few meters by Shishkina and other workers in shallow sediments (see review in Manheim and Chan, 1974).

Evidence for continuing bacterial activity is suggested by the high $\mathrm{NH}_{4}$ values with depth. Owing to the net uptake of $\mathrm{K}$ on silicate matrices, the ammonia exceeds $\mathrm{K}$ at depth in every site, and becomes a significant major constituent, though at lower levels than $\mathrm{Ca}, \mathrm{Mg}, \mathrm{Na}$, and $\mathrm{K}$.

The carbonate equilibrium system is complicated by unavoidable problems and uncertainties associated with the drilling process, especially where free methane is degassed from the cores as they are raised from depth. Calculations show that the observed $p \mathrm{H}$, alkalinity, and calcium values yield systems grossly out of equilibrium, as shown in Table 6 .

This calculation shows that the solution in question and probably others high in calcium are highly oversaturated with calcium carbonate. Since long-term oversaturation in situ is not likely, something has probably happened in the course of coring, sampling, and squeezing to create the oversaturation. From past experience and the difference between shipboard and laboratory analyses of calcium we know that samples high in alkalinity frequently experience precipitation of calcium carbonate and loss of both alkalinity and calcium storage; hence the current on-board alkalinities must be a minimum. Factors such as carbonate ion pairing, and alkalinity due to $\mathrm{HS}^{-}, \mathrm{H}_{3} \mathrm{BO}_{3}$ and its related species, phosphates, $\mathrm{OH}$, and fatty acids, contribute to the alkalinity, but are probably counterbalanced by some loss in the latter. This view is strengthened by recent studies of pore fluids taken with in situ samplers (R. Barnes and J. Gieskes, personal communications). Since neither the calcium nor bicarbonate ion is likely to be appreciably lower, the $p \mathrm{H}$ must be too high. Suess (1976) and Hartmann et al. (1973) have shown similar oversaturated conditions. The difference between the calculated $p \mathrm{H}$ value of 5.87 and the measured $p \mathrm{H}$ of 7.15 could be caused by high $\mathrm{CO}_{2}$ partial pressure at depth; loss of $\mathrm{CO}_{2}$ would take place as the cores were raised to the surface and $p \mathrm{H}$ values would rise. Actual precipitation requires some time, hence our ability to measure the high alkalinities if analysis takes place soon after core extraction. 
TABLE 6

Calculation of $p \mathrm{H}$ in Interstitial Water Core 29, 274 Meters, Hole 380A

\begin{tabular}{|c|c|c|c|c|}
\hline Species ${ }^{\circ}$ & Millimolarity & Millimolality & $\mathrm{m}_{\mathrm{i}} \mathrm{z}^{2}$ & \\
\hline $\mathrm{Na}^{+}$ & 596 & 632.7 & 0.6327 & Sal. ref. $(\%) 53.8$ \\
\hline $\mathrm{K}^{+}$ & 5.0 & 5.3 & 0.0053 & Tot. salts $(\%)=52.7$ \\
\hline $\mathrm{NH}_{4}^{+}$ & 8.0 & 8.5 & 0.0085 & $\mathrm{I}=1 / 2 \mathrm{~m}_{\mathrm{i}} \mathrm{z}^{2}$ \\
\hline $\mathrm{Ca}^{2+}$ & 58 & 61.6 & 0.2464 & $\gamma_{\mathrm{Ca}^{2+}}{ }^{2+} .29 \mathrm{~m}_{\mathrm{Ca}^{2+}}$ \\
\hline $\mathrm{Mg}^{2+}$ & 115 & 122.1 & 0.488 & $\gamma_{\mathrm{HCO}_{3}}{ }^{-}=0.60 \mathrm{~m}_{\mathrm{HCO}_{3}-}$ \\
\hline $\mathrm{Cl}^{-}$ & 934 & 991.5 & 0.991 & where $\mathrm{m}_{\mathrm{i}}=\underset{\text { mon } \mathrm{i}}{\text { molyty of }}$ \\
\hline $\mathrm{SO}_{4}{ }^{2-}$ & 2 & 2.1 & 0.0084 & $z=$ charge \\
\hline $\mathrm{HCO}_{3}^{-{ }^{-b}}$ & 11.9 & 12.6 & 0.0126 & $\gamma=$ activity \\
\hline I (ionic st & trength) & & 1.197 & \\
\hline Total & & & 2.394 & \\
\hline $\mathrm{K}_{\mathrm{CaCO}_{3}}$ & $=10^{-8.3}=$ & $\frac{(\mathrm{Ca})\left(\mathrm{CO}_{3}\right)}{\left(\mathrm{CaCO}_{3}\right)}$ & & (Eq. 1) \\
\hline $\mathrm{K}_{\mathrm{H}_{2}} \mathrm{CO}_{3}$ & $=10^{-6}=$ & $\frac{(\mathrm{H})\left(\mathrm{HCO}_{3}\right)}{\left(\mathrm{H}_{2} \mathrm{CO}_{3}\right)}$ & & (Eq. 2) \\
\hline $\mathrm{K}_{\mathrm{HCO}_{3}^{-}}=$ & $=10^{-10.3}=$ & $\frac{(\mathrm{H})\left(\mathrm{CO}_{3}\right)}{\left(\mathrm{HCO}_{3}\right)}$ & & (Eq. 3) \\
\hline \multicolumn{5}{|c|}{$\begin{array}{l}\text { Combining Equations 1-3, eliminating }\left(\mathrm{CO}_{3}\right) \text { and }\left(\mathrm{H}_{2} \mathrm{CO}_{3}\right) \text {, letting } \\
\text { alkalinity }=\mathrm{HCO}_{3}^{-} \text {and applying activities to equation } 4 \text {, we solve for } \\
\text { pH }\end{array}$} \\
\hline \multirow{2}{*}{\multicolumn{5}{|c|}{$\begin{aligned} p \mathrm{H} & =\log 10^{-8.3}-\log 10^{-10.3}-\log \gamma \mathrm{Ca}^{2+-\log \gamma} \mathrm{HCO}_{3}- \\
p \mathrm{H} & =-8.3+10.3-\log (0.29) \times(0.0616)-\log (0.0126)(0.60) \\
& =5.87\end{aligned}$}} \\
\hline & & & & \\
\hline \multicolumn{5}{|c|}{ Given $p \mathrm{H}=7.15$, what should $\left(\mathrm{HCO}_{3}\right)^{-}$be? } \\
\hline
\end{tabular}

${ }^{a} \mathrm{Na}, \mathrm{K}$, and $\mathrm{NH}_{4}$ interpolated from curves in Figure 6.

${ }^{b}$ Letting $\mathrm{HCO}_{3}^{-=}$alkalinity.

Seen schematically, the process is shown in Figure 10 , with true $p \mathrm{H}$ in situ being 6.0 or less. At $p \mathrm{H} 6$ carbonate species are equally divided between $\mathrm{H}_{2} \mathrm{CO}_{3}$ and $\mathrm{HCO}$ ions, implying a high $\mathrm{pCO}_{2}$ pressure. At $p \mathrm{H} 7.15$ $\mathrm{pCO}_{2}$ should be reduced to a tenth of the in situ values. Seen in this fashion, one may use the degree of oversaturation with $\mathrm{CaCO}_{3}$ as a rough measure of in situ $\mathrm{pH}$ and $\mathrm{pCO}_{2}$, provided that analyses of $\mathrm{Ca}$ and carbonate alkalinity are made immediately after core recovery and fluid extraction.

A further factor may be considered: source of carbonate ion and $\mathrm{CO}_{2}$. We know from piston core studies summarized by Manheim and Chan (1974) that organic carbon oxidized by sulfate-reducing bacteria forms bicarbonate that reaches a maximum in the first few meters of sediment where all sulfate is consumed. Thereafter (with depth) no additional $\mathrm{CO}_{2}$ whose oxygen is derived from pore fluid $\mathrm{SO}_{4}$ can be expected, except insofar as pore fluids in the hypersaline sections of the sediments contained originally higher $\mathrm{SO}_{4}$ concentrations. No significant evidence of $\mathrm{SO}_{4}$ anomalies can now be noted.

Other sources of $\mathrm{CO}_{2}$ and derivative alkalinity may be obtained from reaction of fatty acids or

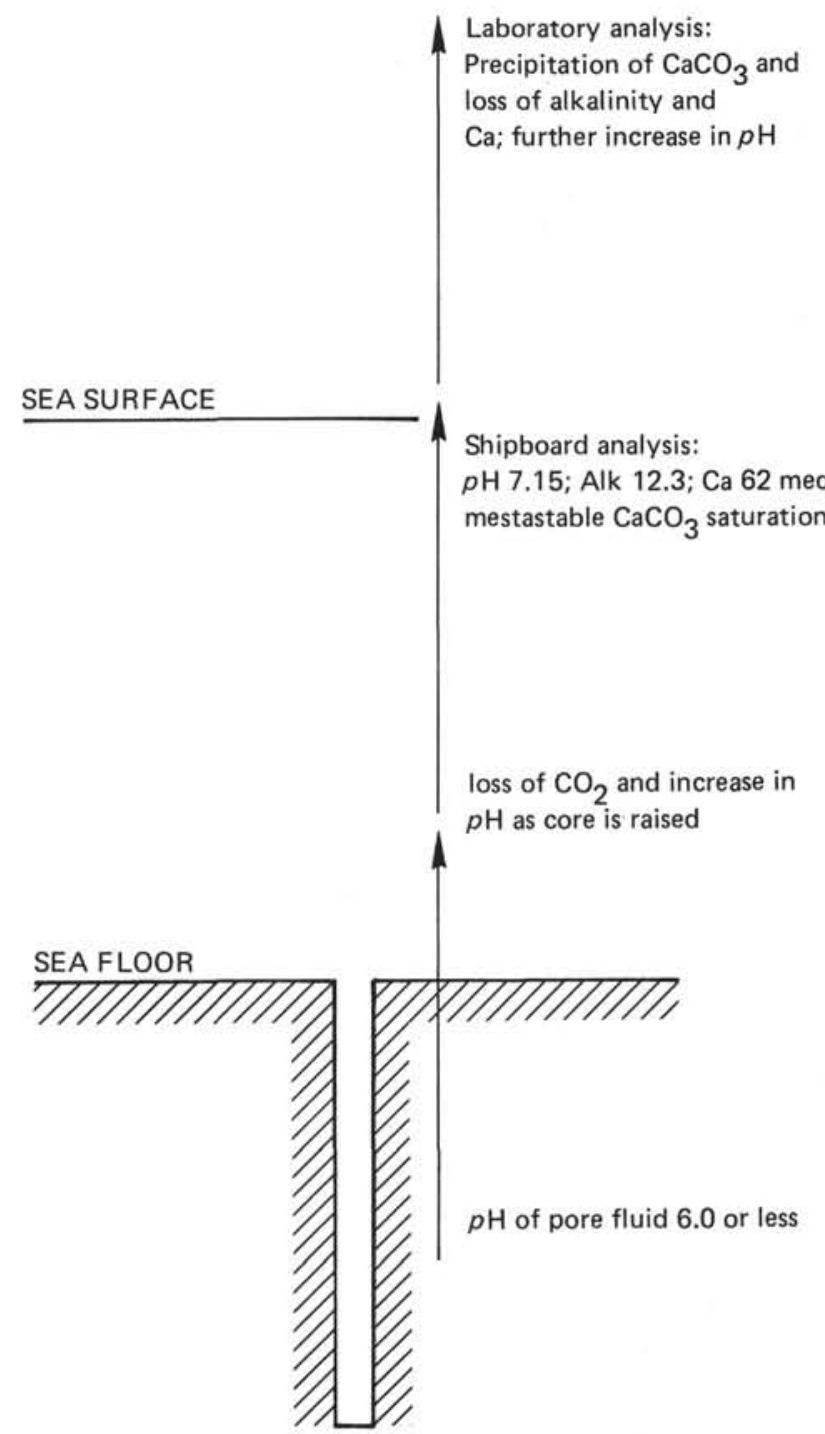

Figure 10. Schematic interpretation of changes in carbonate equilibrium in pore fluid regime, based on Core 29 , Hole $380 \mathrm{~A}$.

decarboxylation of organic matter. It is clear from the chemical analyses of the Soviet and other chemical laboratories that organic carbon is relatively scarce in the deeper strata characterized by high interstitial salinities, until the Pliocene is reached. However, some $\mathrm{Br}$ is added to the solution through probable decomposition of $\mathrm{Br}$-containing organic matter in Holes 379A, B, for example, Shishkina (this volume).

Thus, in conclusion, apparent concentration gradients in free $\mathrm{CO}_{2}$ and hydrogen ion $(p \mathrm{H})$ must exist at depth. An interesting consequence of such gradients is that $\mathrm{H}^{+}$ion, which has a diffusion coefficient roughly four times greater than that of most dissolved gases and 10 fold greater than that of bicarbonate ion, should migrate upward more rapidly, inducing a "front" of carbonate dissolution and reprecipitation. Of course, the hydrogen ion's excess charge must be balanced and therefore "drag" with it other negative ions resulting in a net movement slower than $\mathrm{H}^{+}$ion's diffusion coefficient. 


\section{ACKNOWLEDGMENT}

The assistance of Victor Sotelo in shipboard sampling and analysis is acknowledged; other shipboard colleagues aided materially in obtaining and interpreting the pore fluid data. Finally, we wish to thank Leo Barnard and Jenny Simonsen for their assistance with the autoanalyzer and sulfate analyses.

\section{REFERENCES}

Brewer, P.G. and Riley, J.P., 1966. The automatic determination of silicate-silicon in natural waters with special reference to seawater: Anal. Chim. Acta, v. 35, p. 514-519.

Bruevich, S.V. and Shishkina, O.V., 1969. O paleogidrologii Chernogo morya v pozdnechetvertichnoya vremya (On the paleohydrology of the Black Sea in late Quaternary time): Akad. Nauk SSSR, Dokladv, v. 127, p. 673-676.

Cescon, B.S. and Macchi, G., 1973. A microvolumetric method for the determination of sulfate in pore water. In Heezen, B.S., McGregor, I.D., et al., Initial Reports of the Deep Sea Drilling Project, Volume 20: Washington (U.S. Government Printing Office), p. 811-812.

Daidbekova, E.A., Babaeva, R.S., Grigoriantz, Z.G., Kurbanova, F.M., Ibragimova, B.M., and Shamailova, O.D., 1965. Granulometricheskie tipy porod $\mathrm{i}$ allotigennye mineraly (Granulometric types of rock and allocthonous minerals). In Strakhov, N.M. (Ed.), Postsedimentatsionnye izmeneniya Chet vertichnykh i pliotsenovykh glinistykh otlozhenii Bakinskogo Arkhipelaga (Postsedimentary changes in Quaternary and Pliocene clayey deposits of the Baku archipelago): Moscow (Izdatel'stvo Nauka), p. 29-67.

Hartmann, M., Muller, P., Suess, E., and van der Weijden, C.H., 1973. Oxidation of organic matter in recent marine sediments; "Meteor' Forschungsergebnisse, v. 12, p. 74-86.

Kruikov, P.A., 1971. Gornye pochvennye i ilovye rastory (Interstitial fluids of rocks sediment and soils), Nauk, Novosibirsk, 220 p.

Mangelsdorf, P.C., Jr., Wilson, T.R.S., and Daniell, E., 1969. Potassium enrichment in interstitial waters of recent marine sediments: Science, v. 165, p. 171-173.

Manheim, F.T. and Chan, K.M., 1974. Interstitial waters of Black Sea Sediments: New Data and review. In Degens, E.T. and Ross, D.A. (Eds.), The Black Sea-geology, chemistry and biology: Am. Assoc. Petrol. Geol. Mem. 20, p. $155-180$.

Manheim, F.T. and Sayles, F.L., 1974. Composition and origin of interstitial waters of marine sediments, based on deep sea drill cores. In Goldberg, E.D. (Ed.), The sea: v. 5, New York (Wiley and Sons), p. 527-568.

Mulder, C.J., Lehner, P., and Allen, D.C.K., 1975. Structural evolution of the Neogene salt basins in the Eastern Mediterranean and the Red Sea: Geologie en Mijnbouw, v. 5 , p. $208-221$.

Muratov, M.V., 1960. Chetvertichnaya istoriya Chernomorskogo basseina $v$ sravnenii $s$ istoriya Sredizemnogo morya (Quaternary history of the Black Sea basin in comparison with the Mediterranean Sea): Moskovskoe Obshchestvo Ispytatelei Prirody Byull., v. 35, p. 107-123.

Murphy, J. and Riley, J.P., 1962. A modified single solution method for the determination of phosphate in natural waters: Anal. Chim. Acta, v. 27, p. 31-36.

Pushkina, Z.V., 1965. Porovye vody glinistykh porod i ikh izmeneniya po razrezu (pore waters of clayey rocks and their changes with depth). In Strakhov, N.M. (Ed.), Postsedimentatsionnye izmeneniya chetvertichnykh $i$ pliotsenovykh glinistykh otlozhenii Bakinskogo arkhipelaga (Postsedimentary changes in Quaternary and Pliocene clayey deposits of the Baku archipelago): Moscow (Izdatel'st vo Nauka), p. 160-213.

Shishkina, O.V., 1959. Metamorfizatsiya khimicheskogo sostava ilovykh vod Chernogo morya (metamorphism of pore fluids of Black Sea sediments). In Strakhov, N.M. (Ed.), K. poznaniyu diageneza: Mzdatel'stvo Akad. Nauk, SSSR, p. 29-50.

Skopintsev, B.A., 1958. Solevoi sostav vody Chernago morya (salt composition of water of the Black Sea): Doklady Akad. Nauk, v. 119, p. 121-124 (see also references cited).

Suess, E., 1976. Porenlösungen mariner sedimente. Unpubl. Habilitations dissertation: Christian-Albrechts University, Kiel, 193 p.

Tsunogai, S., Nishimura, M., and Nakaya, S., 1968. Complexometric titration of calcium in the presence of larger amounts of magnesium: Talanta, v. 15, p. 385-390.

Volkov, I.I., 1964. O zakonomernostyakh obrazovaniya i prevrashcheniya soedinenii sery $\mathrm{v}$ osadkakh Chernogo morya. (on the modes of formation and transformation of sulfur species in Black Sea sediments). In Strakhov, N.M. (Ed.), Sovremennye osadki morei $i$ okeanov (Recebt sediments of the seas and oceans): Izdatel'stvo Akad. Nauk, SSSR, Moscow, p. 577-596.

Wall, D., 1974. Dinoflagellates in Late Quaternary deepwater sediments of the Black Sea. In Degens, E.T. and Ross, D.A. (Eds.), The Black Sea-geology, chemistry, and biology: Am. Assoc. Petrol. Geol. Mem. 20, p. 364380 .

\section{APPENDIX - DEUTERIUM IN INTERSTITIAL WATER, HOLES 379A AND 381, LEG 42B}

\author{
Kenneth Hardcastle and Irving Friedman, \\ U.S. Geological Survey \\ Denver, Colorado
}

Deuterium was determined on an aliquot of interstitial water by standard techniques. The $\delta \mathrm{D}$ values are given relative to Standard Mean Ocean Water (SMOW). The two sigma precision of measurement is $0.5 \%$. The interpretation of the data will be given in a later publication.

\begin{tabular}{lrrrrrr}
\hline Core & Section & $\begin{array}{c}\text { Depth } \\
(\mathrm{m})\end{array}$ & I.F. \# & $\delta \mathrm{D}$ & $\mathrm{C} 1(\% / \%)^{\mathrm{a}}$ & $\delta \mathrm{D} / \mathrm{C} 1$ \\
\hline Hole 379A & & & & & & \\
4 & 3 & 30 & $3428-2$ & -62 & 2.65 & 23.4 \\
19 & 5 & 176 & 5 & -58 & 2.00 & 29.0 \\
25 & 5 & 232 & 8 & -57 & 2.19 & 26.0 \\
27 & 4 & 250 & 9 & -56 & 1.87 & 29.9 \\
40 & 3 & 373 & 10 & -49 & 3.62 & 13.54 \\
43 & 2 & 390 & 11 & -48 & 5.17 & 9.25 \\
64 & 4 & 583 & 14 & -43 & 19.7 & 2.16 \\
& & & & & & \\
Site 381 & & & & & & \\
01 & 1 & 1.0 & 15 & -17 & 12.5 & 1.36 \\
01 & 2 & 3 & 16 & -23 & 15.7 & 1.46 \\
03 & 3 & 28 & 17 & -32 & 23.5 & 1.36 \\
07 & 5 & 65 & 18 & -30 & 36.0 & .83 \\
19 & 4 & 176 & 23 & -28 & 37.7 & .74 \\
27 & 2 & 240 & 26 & -28 & 38.4 & .73 \\
33 & 4 & 300 & 29 & -29 & 38.7 & .75 \\
37 & 2 & 336 & 31 & -29 & 40.1 & .72 \\
42 & 1 & 380 & 32 & -28 & 32.8 & 1.18 \\
51 & 4 & 471 & 33 & -26 & 23.8 & 1.09 \\
54 & 5 & 500 & 35 & -25 & 21.3 & 1.17 \\
\hline
\end{tabular}

\footnotetext{
${ }^{\mathrm{a}}$ From Manheim and Schug (this volume).
} 